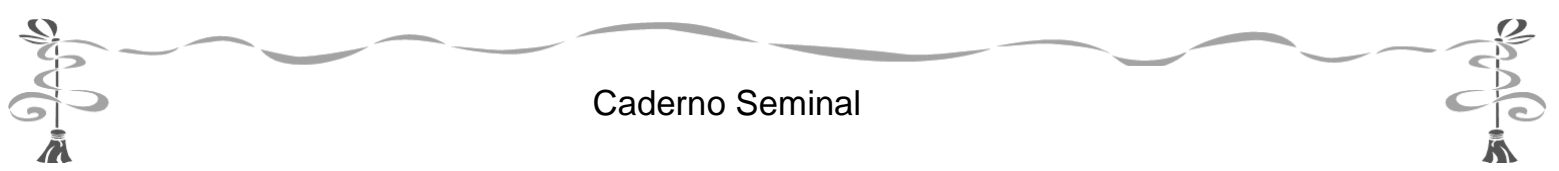

\title{
RADIOGRAFANDO AS COMPETÊNCIAS DO PROFESSOR EM (TRANS) FORMAÇÃO INICIAL DE PROFESSORES DE LÍNGUAS NO PROJETO "TELETANDEM BRASIL: LÍNGUAS ESTRANGEIRAS PARA TODOS"
}

\author{
RADIOGRAPHIC SKILLS TEACHER IN (TRANS) INITIAL TRAINING LANGUAGE TEACHER \\ IN PROJECT "TELETANDEM BRAZIL: FOREIGN LANGUAGES FOR ALL"
}

Kleber Aparecido da Silva ${ }^{62}$

\section{RESUMO}

O presente artigo visa investigar se no processo de formação inicial, desenvolvido no Teletandem Brasil e envolvendo um professor mediador e um par de interagentes (um brasileiro e um estrangeiro), ocorre legitimação de crenças ou (re) construção de competências. Para o desenvolvimento desta investigação, temos como norte a seguinte pergunta de pesquisa: " $A$ professora mediadora legitima as suas próprias crenças e/ ou cria condições para a (re) construção de competências?”. Para responder a esta pergunta, desenvolvemos uma pesquisa de natureza qualitativointerpretativista (BROWN, 1988; NUNAN, 1992; MOITA LOPES, 1994), etnográfica virtual (HINE, 1998; GURIBE \& WASSON, 2002). O referencial teórico é baseado em estudos sobre essas questões realizados em Linguística Aplicada que tiveram como foco o ensino de línguas por meio de (Tele) tandem, o ensino reflexivo e a aprendizagem reflexiva e as competências do professor de línguas para o meio presencial e/ou virtual. No que tange aos reflexos das ações realizadas pela professora mediadora no sistema de crenças do interagente brasileiro, os dados revelam que a professora, por ter sólida formação em Linguística Aplicada e por estar engajada em um curso de pós-graduação Stricto Sensu (Doutorado em Estudos Linguísticos), possibilita meios para que a interagente possa refletir sobre o processo de ensino e aprendizagem de línguas, mostrando que as ações empreendidas pela mediadora nas sessões de mediação não são formas de apenas legitimar as crenças, mas de possibilitar condições para que a interagente (re) construa competências e pense criticamente acerca do seu papel como professora ou como aprendiz de línguas.

Palavras-Chaves: Formação de professores de línguas; Crenças; Competências; Reflexão; Teletandem; Linguística Aplicada.

\section{ABSTRACT}

This article aims at investigating if in the process of initial teacher education developed in the scope of the "Teletandem Brasil" project involving a mediator teacher and two interactants (foreigner and Brazilian) occurs legitimacy of beliefs or (re) construction of competencies. In order to develop this investigation, our research guiding question is: What reflexes can the actions performed by the mediator teacher have on the system of beliefs of the Brazilian interagent? For answering this question it was developed a qualitative-interpretative research (BROWN, 1988; NUNAN, 1992; MOITA LOPES, 1994) and a virtual ethnographic orientation (HINE, 1998; GURIBE \& WASSON, 2002). The theoretical reference is based on studies related to these questions carried out in Applied Linguistics whose focuses were the teaching of English through (Tele) tandem, reflective teaching and reflexive learning and competencies of the language teacher related to the

${ }^{62}$ Universidade de Brasília (UnB). kleberunicamp@yahoo.com.br

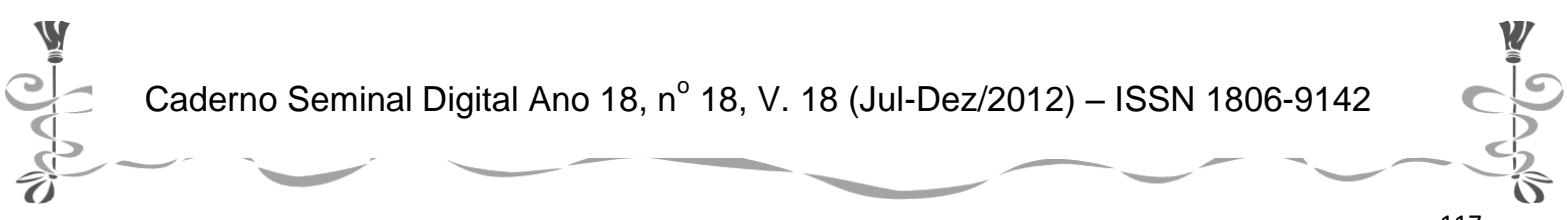




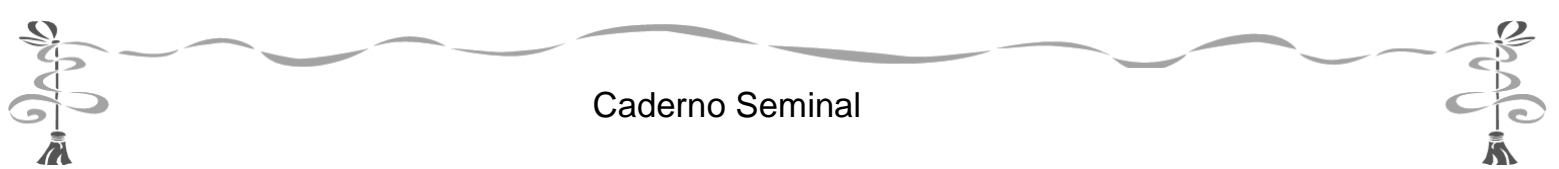

virtual and face-to-face environments. Concerning the reflections of the actions performed by the mediator teacher on the system of beliefs of the Brazilian interactant data reveal that due to her solid formation in Applied Linguistics and her engagement in a Doctorate in Linguistics Studies this teacher in question makes possible the reflection of the interagent about learning and teaching languages, showing that her actions during her mediation sessions are not only ways of legitimating her own beliefs, but also of creating conditions that enable the interactant to (re) construct competencies and to think critically about her role as a teacher or language learner.

Key-words: Teachers Educator; Beliefs; Competences; Reflection; Teletandem; Applied Linguistics.

\section{Introdução}

A sociedade brasileira está em processo de digitalização e/ou de (trans) (multi) letramentos digitais. Por esta razão, a oferta e a procura por cursos ou programas que utilizem interfaces tecnológicas em situação de ensino-aprendizagem e de (trans) formação inicial e/ou contínua de professores de línguas têm sido marcadamente crescentes (cf. FREIRE, 2009; VIEIRA-ABRAHÃO, 2009), sendo necessário que o profissional de línguas, delimite e atravesse as fronteiras digitais, e isto só será possível por meio das práticas de letramento(s) digitais múltiplos (cf. ROJO, 2009, 2005).

Para corresponder a esta caracterização do mercado de trabalho, FREIRE (2009, p 53) afirma que "(...) o professor de línguas se vê diante da necessidade de associar a formação tecnológica a linguística, para que possa incluir/excluir o computador em sua prática docente, no momento adequado e de forma pertinente" (Ênfase adicionada).

No entanto, conforme enfatizado por diversos estudiosos da Linguística Aplicada (doravante LA) e/ou áreas afins (TELLES, 2009; VIEIRA-ABRAHÃO, 2009; SILVA, 2008; ARAÚJO, 2007; TELLES \& VASSALLO, 2006; VASSALLO \& TELLES, 2006; dentre outros), em sua (trans) formação inicial, nem sempre os professores vivenciam atividades instrucionais mediadas pelo computador, e, mesmo quando isto acontece, conforme corroborado por FREIRE (2009, p. 53), "poucas são as chances de discutir o potencial dessa ferramenta e de seus contextos de aplicação, uma vez que seus formadores, em geral, revelam carência de conbecimento na área de tecnologia educacional ou resistência à utilização da máquina e a reflexão crítica sobre suas implicações para o ensino-aprendizagem de linguas" (Ênfase adicionada).

A constatação dessa lacuna na formação inicial ou pré-serviço do professor de línguas contextualiza a proposta deste artigo, que tem por objetivo apresentar e refletir criticamente sobre as competências que são (re) construídas pelos participantes da pesquisa dentro do contexto teletandem ${ }^{63}$. Acreditamos que esta perspectiva nos propiciará subsídios teóricos e práticos, para que o professor de línguas atue com maior eficácia no meio virtual, promovendo, por sua vez, de uma

\footnotetext{
${ }^{63}$ Para uma explicitação mais abrangente do referido contexto e dos estudos empíricos realizados na UNESP (São José do Rio Preto e Assis), veja Telles (2009).
}

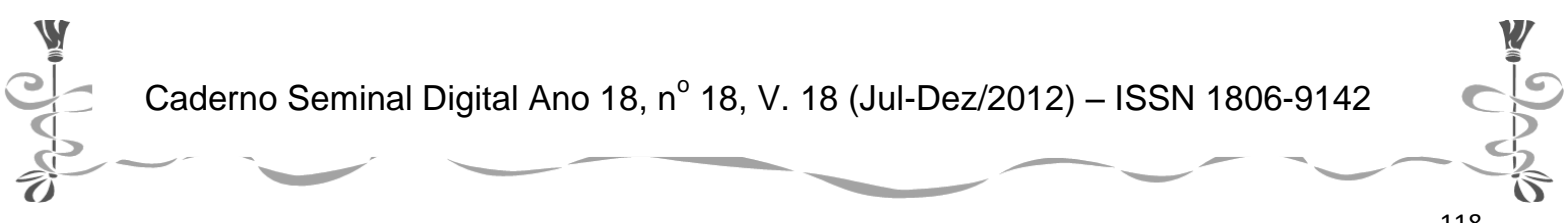




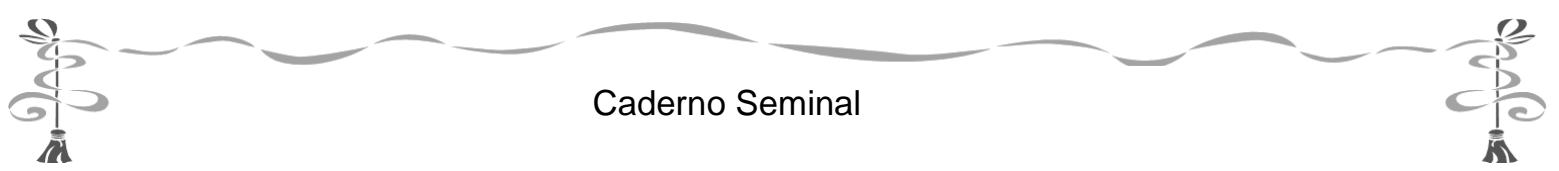

forma articulada, a (re) construção do conhecimento acoplado com uma formação mais sólida e condizente com as demandas da sociedade em que estamos inseridos.

Para tanto, o presente artigo se ancorará no seguinte binômio teórico: a) uma perspectiva de uma (trans) formação inicial de professores de línguas fundamentada nos pressupostos do ensino-aprendizagem e da formação colaborativa e/ou cooperativa (VIEIRA-ABRAHÃO, 2009; FIGUEIREDO, 2006); b) uma visão de (re) construção de conhecimento como processo complexo, contínuo, não fragmentado, e portanto, transdisciplinar (FREIRE, 2009; PAIVA, 2008; MOITA LOPES, 2006; BAKHTIN, 1929/1979, 2003).

Orientados pelo entendimento da LA como campo de investigação transdisciplinar, conforme asseveram CELANI (1998) e ROJO (2006), transgressivo, na perspectiva de PENNYCOOK (2006) ou indisciplinar, como quer MOITA LOPES (2006), procuraremos fazer com que os resultados parciais de nossos estudos possam vir a contribuir e fundamentar nossas ações e teorizações, auxiliando-nos a alcançar a leveza de pensamento (ROJO, 2006) necessária para o (re) encontro de caminhos e formas de abordagens mais condizentes com os paradigmas da contemporaneidade.

\section{O contexto "Teletandem" e a nossa pesquisa: Breves reflexões}

Para SOUZA (2003a, p. 114) e conforme já apresentado por Benedetti no capítulo I desta coletânea, a palavra 'tandem' é usada em referência à bicicleta de dois assentos ${ }^{64}$. Com essa representação pictórica, podemos dizer que a expressão 'aprendizagem em regime de tandem' sugere a cooperação entre dois aprendizes que estarão trabalhando conjuntamente (acrescentamos, ou seja, colaborativamente) em busca do objetivo de aprendizagem de uma lingua estrangeira, tal como dois ciclistas colocando uma única bicicleta em movimento" (Ênfase adicionada). Ou seria como quatro pessoas em um barco e/ou canoa, tendo como objetivo, chegar a determinado lugar. Para tal intento, é imprescindível cooperação e a colaboração entre todos. Isto implica definir prioridades e metas; e negociar com o(s) parceiro(s) as maneiras para atingi-la(s).

Este é o contexto teletandem que envolve um ambiente de ensino-aprendizagem que utiliza webcam, microfone e aplicativos do tipo MSN Messenger, Oovoo ou Skype, a fim de (re) criar uma atmosfera propícia em que a interação entre os pares de falantes nativos (e/ou competentes) de línguas possam trabalhar de forma cooperativa e colaborativa com o intuito de ensinar a sua própria língua e de aprender uma LE (cf. TELLES, 2009).

Conforme corroborado por VASSALO \& TELLES (2006a, p. 190), aprendizagem de LEs in tandem "envolve pares falantes (nativos ou competentes) com o objetivo de aprenderem, cada um, a língua do outro, por meio de sessões bilíngues de

\footnotetext{
${ }^{64}$ O maior tandem do mundo foi construído na Austrália em 1984 e tinha a capacidade de 74 ciclistas, segundo o site eletrônico: http://pt.wikipedia.org/wiki/Bicicleta Tandem.
}

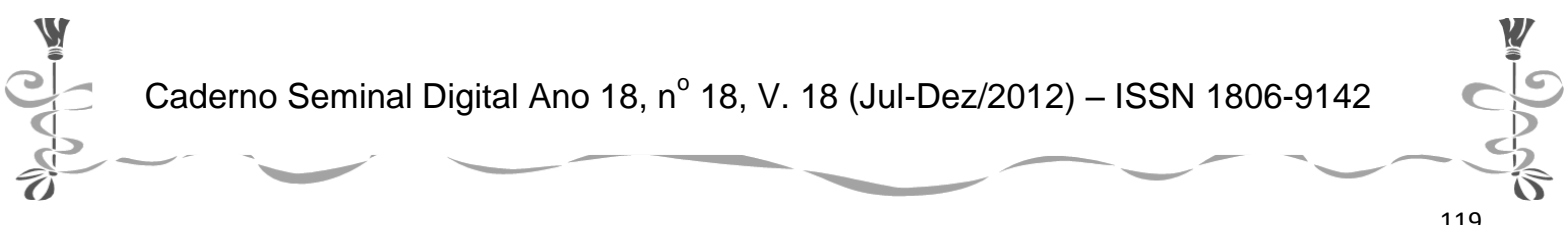




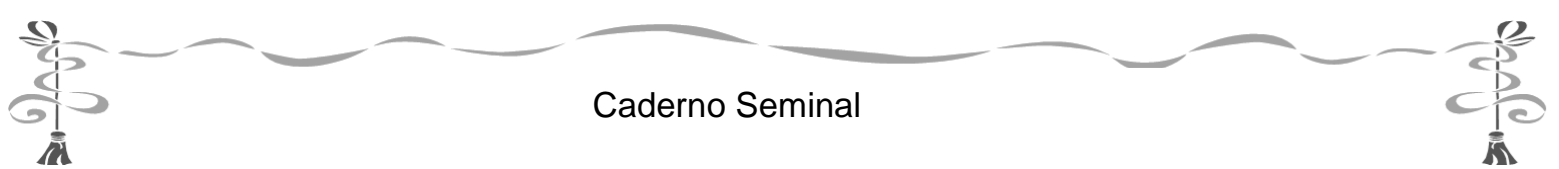

conversação". Certamente, neste contexto autônomo e ao mesmo tempo cooperativo e/ou colaborativo de ensino e aprendizagem de línguas, cada um dos interagentes torna-se aprendiz de uma língua estrangeira e tutor da sua língua materna ${ }^{65}$. Para TELLES (2006, p. 8) o Teletandem é uma nova modalidade de ensino, quando afirma que o Teletandem é

um tandem a distância que faz uso do aspecto oral (ouvir e falar) e do aspecto escrito (escrever e ler), por meio de conferências em áudio/vídeo, utilizando o MSN Messenger 7.5, um aplicativo da Microsoft que dispõe de recursos que permitem que o usuário efetue interações na língua estrangeira com o seu parceiro, utilizando a voz, o texto (leitura e escrita) e imagens de vídeo por meio de uma webcam em tempo real. Além de ser gratuito, o MSN Messenger é mais rápido do que usar o e-mail (comunicação assíncrona) e se constitui em uma opção para conversar (ouvir e falar), para ler e escrever, e para ver o parceiro do outro lado por meio da vídeo-câmera, tudo de forma simultânea (comunicação síncrona)". Diferentemente de amigos que se encontram para conversar e "corrigir" um ao outro, o teletandem se constitui em um novo método de ensino e aprendizagem que permite o acesso democrático e gratuito às línguas estrangeiras (Ênfase adicionada).

Sem dúvida, o Teletandem oferece ferramentas e contextos apropriados para que os participantes geograficamente distanciados, possam praticar virtualmente a produção e a compreensão orais, além das habilidades de leitura e escrita (cf. TELLES, 2009). Dessa forma, tal modalidade (cf. TELLES, 2006), a nosso ver meio elou contexto de ensino-aprendizagem e pesquisa (Ênfase adicionada) pode, ainda, proporcionar, de modo virtual, a aproximação que caracteriza o processo de ensinoaprendizagem do modo face a face ou presencial.

No contexto do projeto temático apresentado em TELLES (2009) e em outros artigos publicados nesta mesma coletânea, três objetivos norteiam $\mathrm{O}$ desenvolvimento das pesquisas do grupo "Teletandem Brasil: Linguas Estrangeiras para Todos". São eles: (a) investigar o funcionamento de aplicativos de mensagens instantâneas via teleconferência (Windows Live Messenger, Skype e Oovoo, por exemplo) como ferramentas e contextos multimediais para a aprendizagem de línguas estrangeiras in-tandem a distância; em particular os seus recursos de vídeo e de som na interação oral e escrita em língua estrangeira; b) verificar os processos de interação e de aprendizagem entre os pares de jovens, participantes do tandem a distancia; c) analisar os quesitos necessários à formação inicial e contínua do

\footnotetext{
${ }^{65}$ Estamos conscientes de que o "professor mediador" e/ou "mediador" também seja um "interagente" e "um mediador". Porém, quando fizermos menção ao termo "interagente" estamos nos referindo aos "participantes" brasileiro ou estrangeiro, embora saibamos que o "professor mediador" ou "mediador" também interage nas sessões de mediação com o interagente brasileiro, e oposto também é verdadeiro. A nosso ver, é preciso que encontremos na literatura em LA talvez um termo mais adequado para se referir aos participantes desta pesquisa, sejam eles os "interagentes" e os "professores mediadores".
}

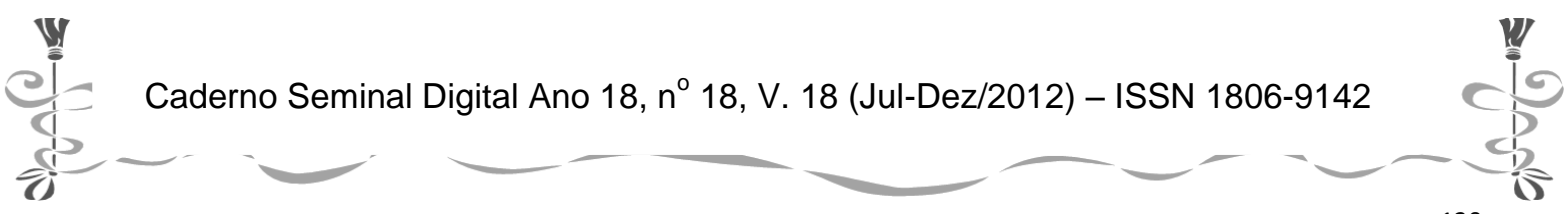




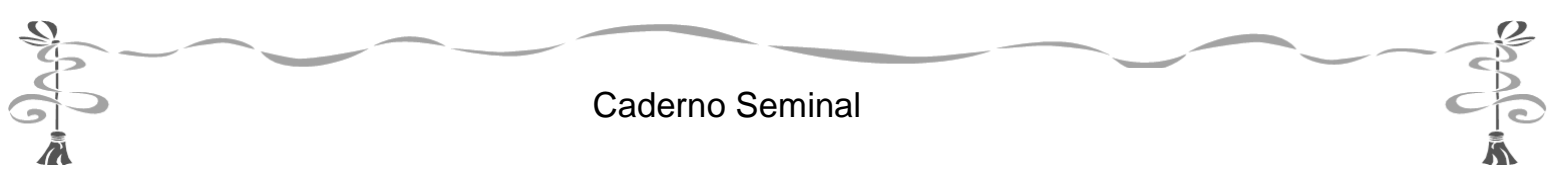

professor e seu papel de professor e mediador da aprendizagem neste novo contexto interativo de ensino/aprendizagem de línguas estrangeiras em in-tandem a distância.

Desta forma, o presente estudo empírico de doutorado intitulado “O professor mediador e os interagentes (brasileiro e estrangeiro) no Teletandem Brasil: Legitimação de crenças e/ou (re) construção de competências?", se insere no terceiro objetivo de pesquisa, mais especificamente no subprojeto guarda-chuva intitulado "O professor mediador: crenças, ações e seus reflexos nas práticas docentes dos pares envolvidos no tandem à distância"66. Pretende-se investigar se no processo de formação inicial, desenvolvido no Teletandem Brasil e envolvendo um professor mediador (que desempenha o papel de formador de professor) e os interagentes (brasileiro e estrangeiro, mas tendo como participante primário o interagente brasileiro), que desempenham concomitantemente os papéis de professor/aluno, ocorre legitimação de crenças e/ou (re) construção de competências.

Vale ressaltar que há poucos estudos empíricos na LA brasileira que tenham, por sua vez, investigado as variáveis apresentadas preliminarmente, ou seja, o ensino de línguas por meio de MSN Messenger integrando, de forma síncrona e/ou assíncrona, as quatro habilidades e que investiguem especialmente a (trans) formação inicial do professor e do formador de professores de LE (MENDES, 2009; BEDRAN， 2008; KFOURI-KANEOYA， 2008; MESQUITA， 2008; SALOMÃO, 2008) para o meio virtual. Este cerne é de suma importância e foi justamente o foco investigativo do nosso estudo empírico, e neste artigo apresentaremos um pequeno recorte, contemplando, por sua vez, uma radiografia parcial das competências do professor mediador que emergiram a partir da análise dos dados num contexto virtual.

\section{Competências do professor contemporâneo de língua estrangeira: Reflexões e considerações conceituais e terminológicas}

Esta seção tem por objetivo fundamentar a análise de dados, por esta razão, apresentaremos reflexões e considerações acerca do termo competência sob o olhar da LA e, a seguir, apresentaremos as competências já elicitadas em estudos empíricos do referido campo de investigação, tendo como escopo o âmbito presencial e/ou virtual.

Neste estudo o conceito de competências é entendido como a capacidade de saber fazer, ser capaz de agir em determinadas situações, fazendo uso de conhecimentos construídos (cf. BASSO, 2001). Segundo PERRENOUD (2001), a competência pode ser concebida como a capacidade do indivíduo de agir eficazmente em um determinado tipo de situação, apoiando-se em conhecimentos, sem, contudo,

\footnotetext{
${ }^{66}$ Este subprojeto de pesquisa é de responsabilidade da Profa Dra Maria Helena Vieira-Abrahão, vice-coordenadora do Projeto “Teletandem Brasil: Línguas Estrangeiras para Todos" (CNPQ/FAPESP).
}

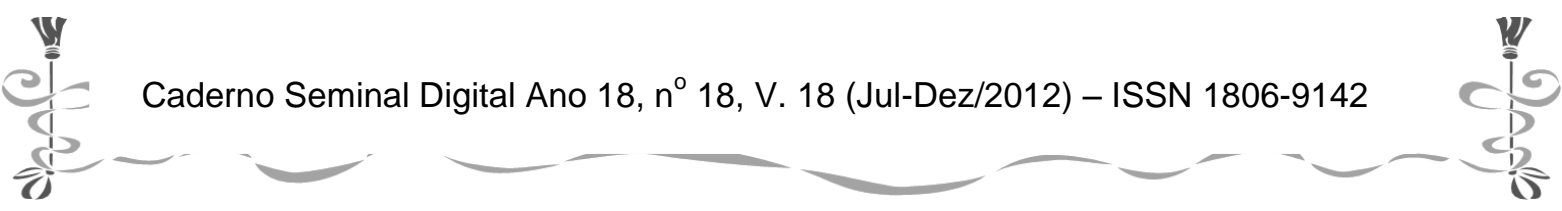




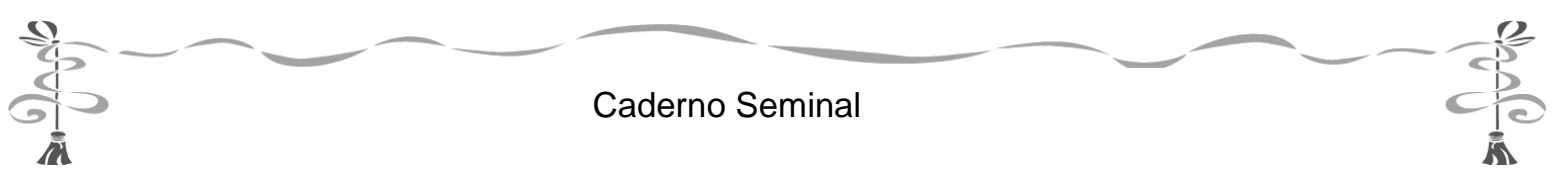

limitar-se a eles. O autor assevera, ainda, que a competência é a faculdade de mobilizar recursos cognitivos - como saberes, habilidades e informações - para solucionar, com pertinência e eficácia, uma série de situações.

PERRENOUD (2001, p. 148) prossegue afirmando que podemos definir saberes como "o conjunto de conhecimentos que apresentam certa unidade em virtude de suas fontes e objetivos", sendo que os mesmos, conforme apontam SADALLA et al (2002), podem reunir-se segundo diferentes categorias e tipologias, tais como saberes científicos, eruditos, do senso comum, da experiência, entre outros. É importante ressaltar que o professor se apropria dos saberes de "forma única e subjetiva", sendo os mesmos "construídos e desconstruídos na prática" (SADALLA et al, 2002, p. 59).

De acordo com SADALLA et al (2002, p. 61), é exatamente o caráter reflexivo que possibilita uma relação adequada entre saberes e competências, uma vez que na ausência da reflexão, tais conceitos estariam relacionados a habilidades pura e meramente técnicas. Conforme já explicitado, PERRENOUD (2000, p. 15) afirma que competência é "uma capacidade de mobilizar diversos recursos cognitivos para enfrentar um tipo de situação”. Deste modo, segundo SADALLA et al (2002, p. 61), podemos entender a competência (do professor) não como um saber ou atitude, mas sim, como "a capacidade de mobilizar determinados saberes, atitudes e esquemas de pensamento, como recursos para agir numa determinada situação, adaptando-se da melhor maneira a ela" (Ênfase adicionada).

Dentro desta perspectiva, entendemos que a competência não pode ser relacionada à imitação de modelos ou ao acúmulo de conhecimentos, uma vez que ela envolve a ação de resolver problemas e, portanto, fazer escolhas, apoiando-se em conhecimentos já (re) construídos, ao mesmo tempo em que se buscam e se (re) constroem novos conhecimentos. É pertinente ressaltar que, na medida em que pressupõe a (re) construção de saberes e a existência de aprendizagens para que se possa identificar e encontrar conhecimentos pertinentes a uma dada situação (BARBOSA, 2001), o conceito de competência abarca a mobilização de conteúdos.

Contudo, é relevante salientarmos que as competências não são conteúdos em si, sendo este o ponto que distingue uma abordagem embasada na (re) construção de competências de uma abordagem essencialmente cognitivista, centrada unicamente na "ampliação de conhecimentos e distinção de conteúdos" (BARBOSA, 2001, p. 102). Ao propor o conceito, PERRENOUD (1999) advoga nessa direção, enfatizando que a apropriação de uma competência é mais que a simples internalização de conteúdos factuais ou conceituais e que a mobilização de saberes não deve ser confundida com conhecimento acumulado.

O processo educativo, destaca o autor, envolve tempo de trabalho e reflexão, o que, por sua vez, implica a construção de conhecimento através da ação e menor ênfase nos conteúdos (formais). Conforme salienta BARBOSA (2001, p. 104), para

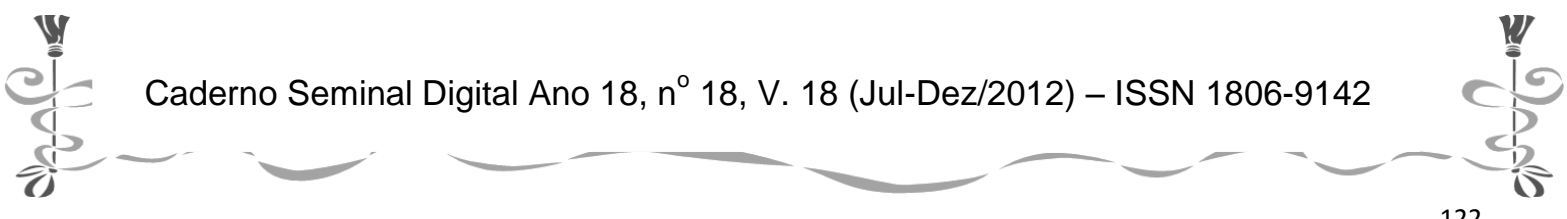




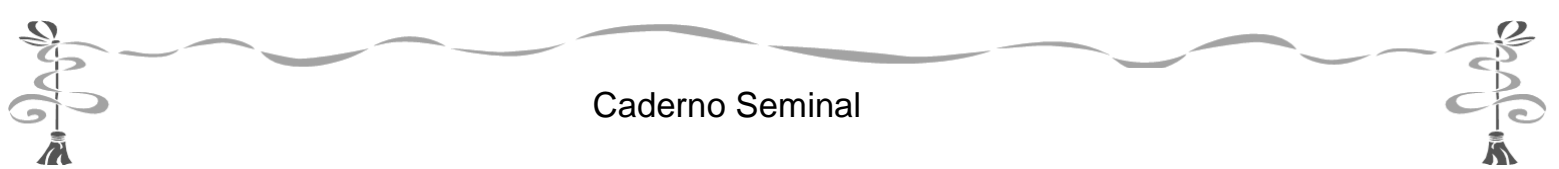

PERRENOUD (1999), ao construirmos o processo de ensino-aprendizagem, "há algo mais em jogo, para além de conteúdos na realização de ações - sejam elas verbais ou não".

Desta forma, a ênfase recai na importância do ensino como promotor do desenvolvimento integral do aluno e na relevância das relações sociais no processo de construção do conhecimento. Nessa perspectiva, entendemos ser o conceito de competência compatível com a visão de ensino-aprendizagem como co-construção de conhecimentos (VYGOTSKY, 1998, 2001), uma vez que, distante de abordagens assimilativas e conteudistas (gramaticalistas), "ele traz em si uma referência a situações práticas e sociais” (BARBOSA, 2001, p. 102).

PERRENOUD (2001) enfatiza, ainda, que a associação entre as ideias de competência e de mobilização de saberes está intimamente ligada à construção da cidadania e da postura crítica do indivíduo. A este respeito, BARBOSA (2001, p. 101) pontua que o que sustenta uma abordagem apoiada no conceito de competências é, também, a acepção de que abordagens tradicionais, calcadas no acúmulo de informações, não preparam o indivíduo "para que ele possa ter igualdade de oportunidades no mundo atual" ou tampouco são capazes de promover a reflexão através do processo de ensino-aprendizagem.

Segundo CRISTOVÃO (2005, p. 106), os sentidos dos conceitos de competencia, capacidades, habilidades e conhecimentos "são muito próximos", o que nos leva a compreender que o entendimento desses termos depende do posicionamento teórico e, consequentemente, da visão dos autores que os utilizam para tecerem considerações sobre o processo educativo. BARBOSA (2001) caminha na mesma direção, enfatizando que a noção de competência, assim como outras terminologias, a saber, habilidades, capacidades, estratégias, dentre outras, são complexas, podendo ser, na maioria das vezes, problemáticas. $\mathrm{Na}$ acepção da autora, isto pode ocorrer porque esses conceitos mostram-se inespecíficos e insuficientes ou, ainda, porque carregam traços de perspectivas teóricas distintas.

Ressaltamos que, para BRONCKART \& DOLZ (1999), na área da Didática de Línguas, por exemplo, o conceito de competência deve ser abandonado em favor do conceito de capacidade. De acordo com CRISTOVÃO (2005, p. 107), os autores citados, ao fazerem "uma retrospectiva histórica das concepções de competência desde o século XV", entendem que o referido conceito carrega, ainda, conotações que acentuam concepções inatistas em relação à aquisição da linguagem.

A autora acrescenta que, na acepção de BRONCKART \& DOLZ (1999), o termo capacidade, por sua vez, "estaria relacionado com a dimensão da aprendizagem, exigindo do sujeito sua participação prática no processo" (CRISTÓVÃO, 2005, p. 108). Esse posicionamento, contudo, encontra-se em conflito com o pensamento de outros teóricos da área (BASSO, 2008, 2001; BARBOSA, 2001; ALMEIDA

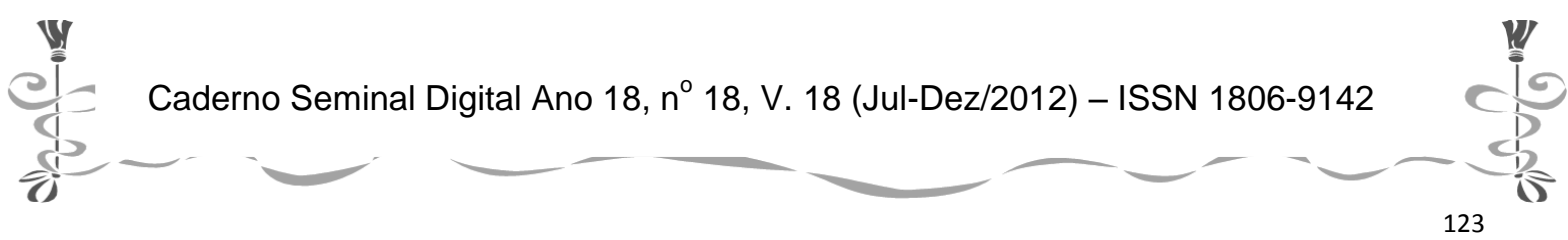




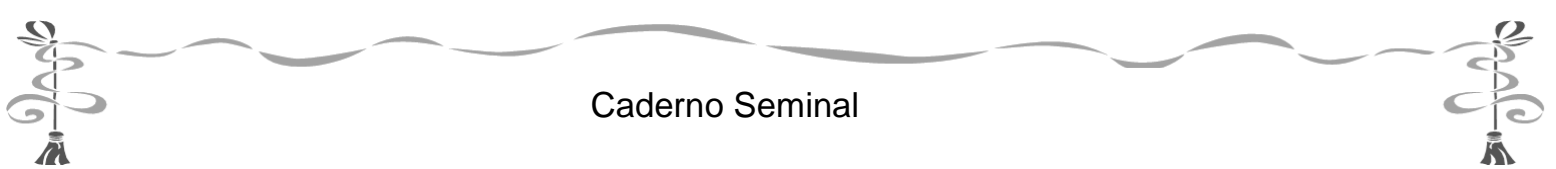

FILHO, 1999, 1993; dentre outros), os quais fazem uso do termo competência em seus trabalhos, distanciando-se de postulações de cunho chomskiano.

No entanto, não temos como objetivo principal neste artigo, aprofundar as questões terminológicas desses conceitos. Privilegiamos, aqui, a noção de competência defendida por ALMEIDA FILHO (2006, 2004, 1999, 1993) e BASSO (2008, 2001), entendendo o termo capacidades como direta e intrinsecamente relacionado ao primeiro. Convergimos, portanto, com CRISTOVÃO (2005, p. 107) a este respeito, uma vez que a citada autora afirma que podemos "perceber uma relação bastante direta entre capacidade e competência, capacidade e habilidade", na medida em que, ao serem abordados na Educação (PERRENOUD, 1999, 2000, 2001) ou na LA (MOITA LOPES, 1996; ALMEIDA FILHO, 1993, DENTRE OUTROS), geralmente "um conceito é usado para explicar o outro".

Assim, é importante ressaltar que, em nosso estudo, ancorando-nos em BARBOSA (2001) e CRISTOVÃO (2005), fazemos uso de ambos os termos indistintamente, abordando-os como algo (re) construído através das interações sociais e mobilizado "por redes advindas da apropriação de práticas sociais, discursos e conhecimentos" (BARBOSA, 2001, p. 105). Desta forma, nosso foco, ao nos referirmos a tais conceitos, distancia-se dos conflitos terminológicos e recai na importância dos mesmos em relação à construção de objetivos para o ensino de línguas, os quais, por sua vez, devem estar, em nosso contexto, vinculados à acepção vygotskyana de que "é na ação conjunta que a linguagem se torna significativa" (MIRANDA, 2005, p. 15) e na relevância da cultura para o processo.

\section{As competências de um professor de LE no meio presencial e/ou virtual}

Nesta parte do artigo tomaremos como referencial o modelo teórico proposto por ALMEIDA FILHO (2006, 2004, 1999, 1993) e os que tiveram o mesmo por inspiração (BASSO, 2008, 2001), os quais evidenciam as competências que consideramos desejáveis ao profissional atuante no processo de ensino e aprendizagem de LE, conforme ilustrado a seguir.

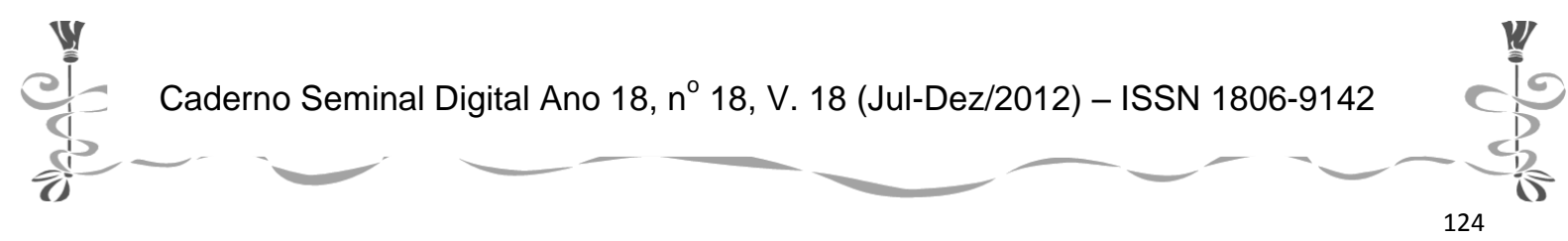



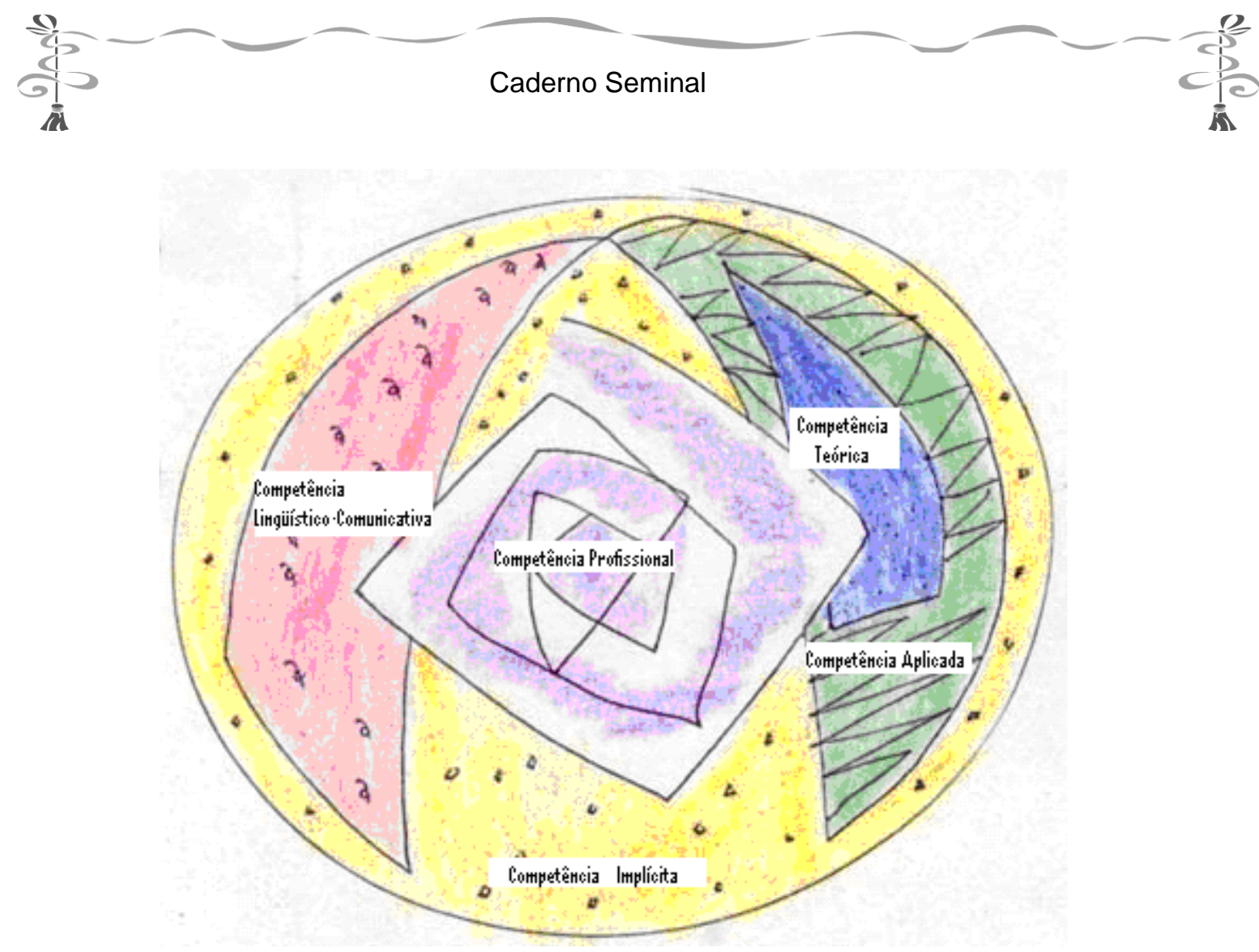

FIGURA 1

AS COMPETÊNCIAS DO PROFESSOR DE LE SEGUNDO ALMEIDA FILHO $(2006,2004,1993)$

Segundo Almeida Filho (1993, 2004, 2006), quando um professor se coloca no lugar e momento de ensinar, um feixe ou "aglomerado de conhecimentos informais anteriormente construído”, o qual abarca desde percepções, intuições, memórias, sacadas, imagens e crenças $^{67}$ até pressupostos teóricos explícitos, tudo sob uma configuração de atitudes, posta-se a serviço desse ensinar, embasando todas as suas tomadas de decisões. A "qualidade, natureza ou textura da ação de ensinar, portanto, vai depender de uma combinação ou nível de uma ou mais de cinco competências básicas": linguístico-comunicativa, implícita, teórica, aplicada e profissional. Segundo Almeida Filho (1993, 2004, 2006), para ensinar, o professor necessita, no mínimo, das competências linguístico-comunicativa e implícita.

A primeira, a competência linguístico-comunicativa, permitirá ao professor "ensinar o que sabe sobre a língua em questão e envolver os aprendentes numa teia de linguagem na língua-alvo". A segunda, a competência implícita, lhe facultará "agir espontaneamente para ensinar através de procedimentos tidos como apropriados" (Almeida Filho, 2004, p. 13).

\footnotetext{
${ }^{67}$ Para maiores informações sobre estas categorias de informalidade, veja os estudos de Bandeira (2003), Silva (2005) e Silva, Rocha e Sandei (2005).
}

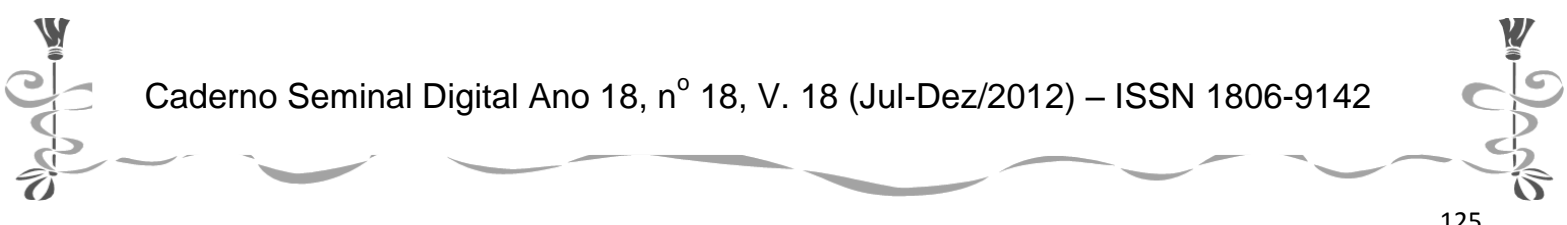




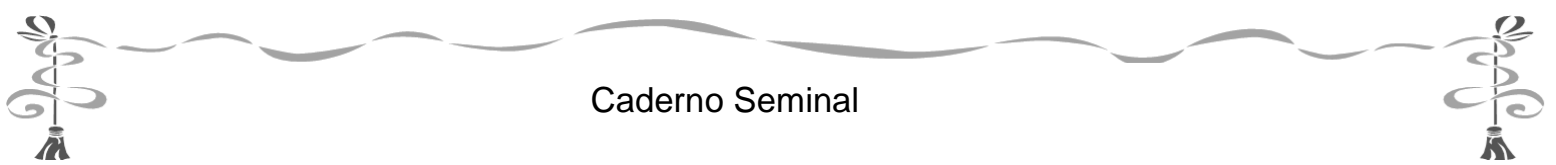

$\mathrm{Na}$ medida em que o professor avança na sua profissionalização, crescem as chances desse profissional desenvolver competência teórica sobre os processos de ensinar e aprender línguas conhecidos em teorizações de autores e pesquisadores. Tal competência "requer que se saiba e se saiba explicar por meio de termos e teorizações explícitas e articuladas como se dá o processo de ensinar e aprender língua(s)" (Almeida Filho, op. cit: 13).

Essa competência interfaceia com a competência implícita, visando equilibrar o "saber dizer" com o "saber fazer", desfazendo a dicotomia teoria-prática que sempre nos assombra na profissão. Nessa perspectiva, segundo o citado autor, começa-se fazendo (ensinando e aprendendo) simplesmente e, ao mesmo tempo, gradualmente aprende-se a explicar satisfatoriamente esse processo.

A competência de ensinar que sintetiza essas duas competências é a competência aplicada, "um misto de teoria e prática na medida do seu ajuste possível num dado momento" (Almeida Filho, op. cit. 13). Para balizar o desenvolvimento parcial de cada competência e sinalizar os horizontes profissionais desejados, insinua-se uma competência profissional. Nas palavras de Almeida Filho (op. cit.: 13)

"Essa capacidade macro-sistêmica de reconhecer-se profissional, de reconhecer padrões nas redes sociais em que circulam e de buscar ajuda no aperfeiçoamento constitui o domínio dessa competência consciência de si e das outras".

Basso (2001), inspirada no modelo proposto por Almeida Filho (1993), propõe uma equação de competências necessárias a um professor de LE constituída de duas faces, conforme pode ser observado na figura a seguir.

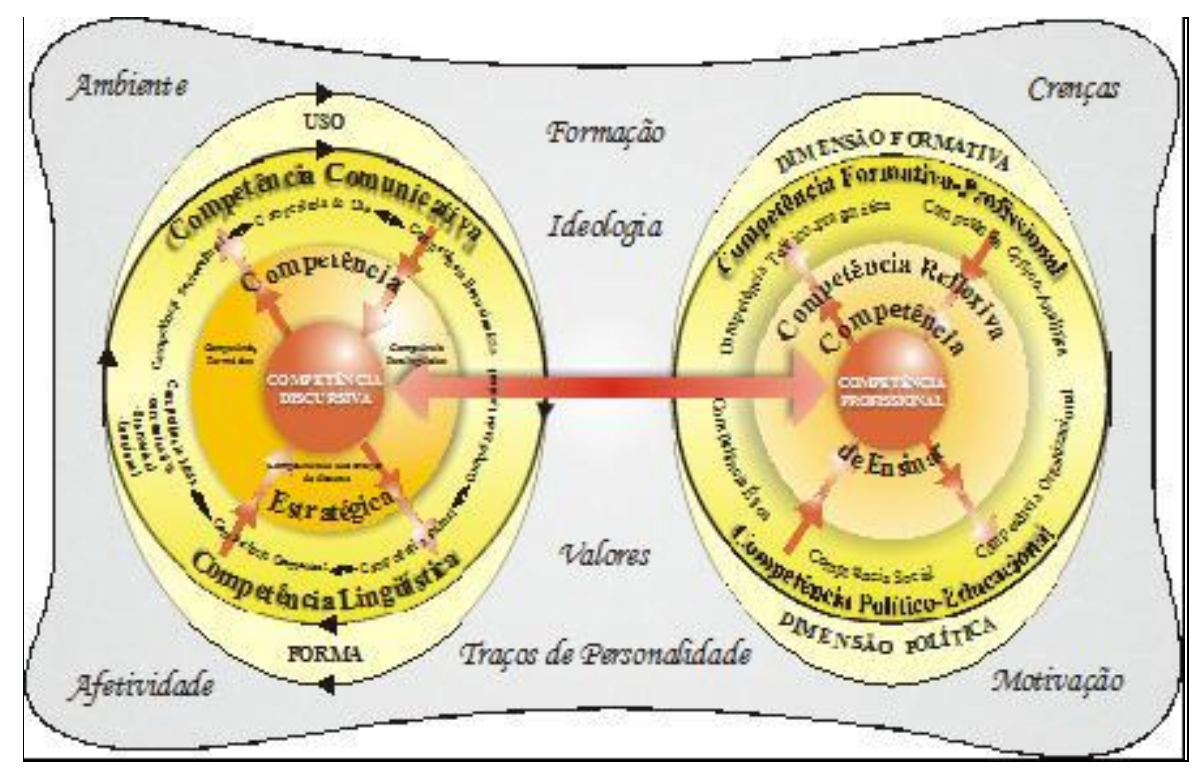

FIGURA 2

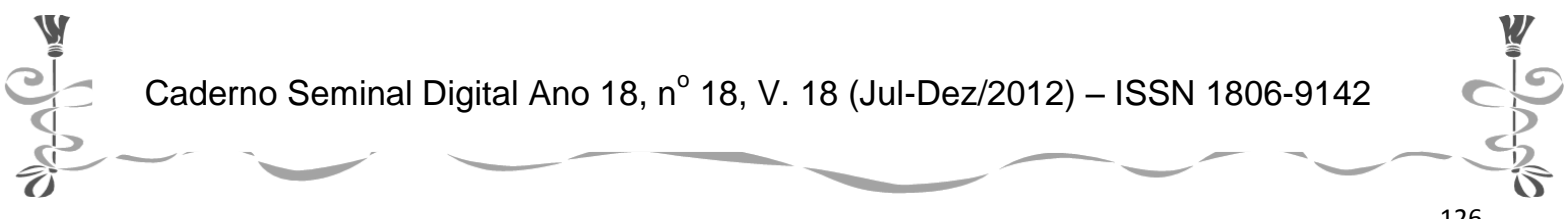




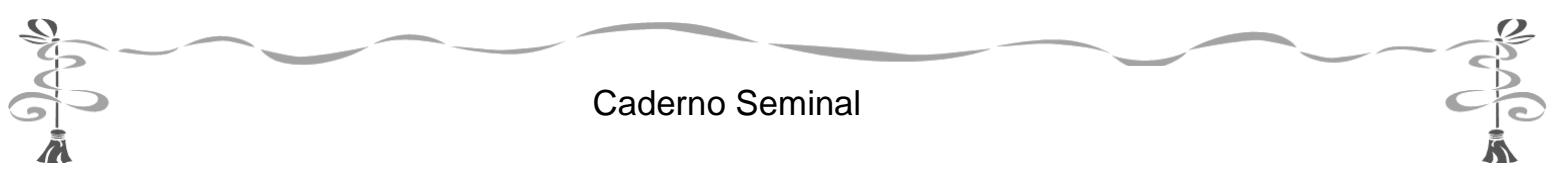

AS COMPETÊNCIAS DO PROFESSOR DE LE SEGUNDO BASSO (2001)

$\mathrm{Na}$ primeira face apresenta as competências do professor relativas ao domínio do uso e da forma da LE: Competência Discursiva, composta pelas Competências Estratégica, Comunicativa, Linguística e Competência Meta. Na outra face, a autora propõe o conceito de Competência Profissional, circundada pela Competência de Ensinar; a Competência Reflexiva, isto é, "a capacidade de refletir e buscar soluções para os problemas que enfrenta no cotidiano".

Por último, chega-se, de acordo com a autora, à dimensão maior da Competência Profissional que é de "educar para o futuro, transformando o presente; de ser não somente o que informa, mas o que forma; não o que repassa somente um código, mas que aponta caminhos aos alunos para que transformem através dos novos horizontes de possibilidades abertos pela nova língua" (Basso, 2001).

Basso (2001) optou por não utilizar o conceito "competência aplicada" por dois motivos fundamentais: primeiro, o mesmo se encontra no conceito proposto pela referida autora (competência reflexiva); segundo, a palavra "aplicada" poderia ser facilmente confundido com "aplicações de teorias linguísticas" (cf. Claus, 2005).

Vale salientar que os estudos sobre competências desenvolvidos na LA brasileira tiveram como escopo o âmbito presencial, e neste estudo analisaremos as competências do professor de línguas no âmbito virtual.

\section{Metodologia de Pesquisa}

Trata-se de uma pesquisa qualitativa, de base etnográfica virtual (André, 2003; Guribe \& Wasson, 2002; Hine, 1998), caracterizada pela descrição e estudo de situações concretas e singulares; e pela consideração da perspectiva dos participantes da pesquisa.

A pesquisa foi realizada em um contexto virtual de ensino-aprendizagem e de (trans) formação inicial e contínua de professores de línguas, e envolveu um professor mediador (uma aluna de doutorado de um reconhecido programa de pós-graduação Stricto Sensu em Estudos Linguísticos), um interagente brasileiro (uma aluna do curso de Letras de uma universidade pública, localizada numa cidade de porte médio, de um estado do sudeste brasileiro) e um estrangeiro (um aluno do curso de "Literatura" numa universidade estadunidense).

Para a coleta dos registros foram escolhidas as seguintes técnicas, utilizadas em pesquisas de base etnográfica: diários de pesquisa por parte da interagente brasileira e do professor mediador; gravação em ándio e vídeo das interações em pares e das interações professor mediador e do seu respectivo interagente brasileiro; autobiografias do professor mediador e do seu respectivo interagente brasileiro com o objetivo de entender as crenças e as suas possíveis origens; e questionários semiestruturados e entrevistas com o objetivo de conhecer melhor os participantes de nossa pesquisa. Estes instrumentos de coleta fizeram parte desta pesquisa, que por

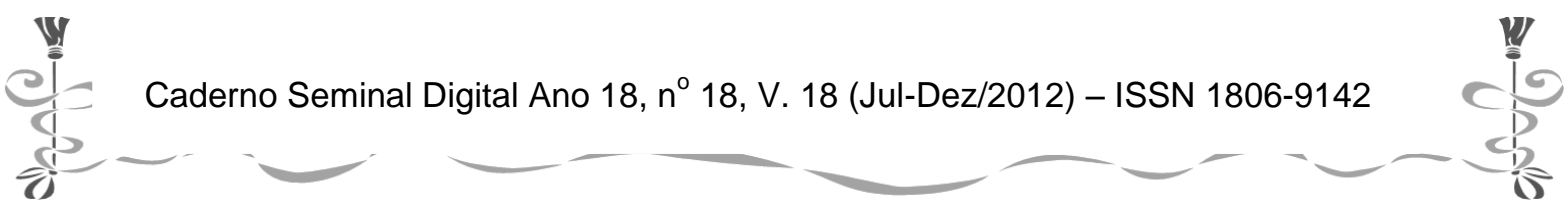




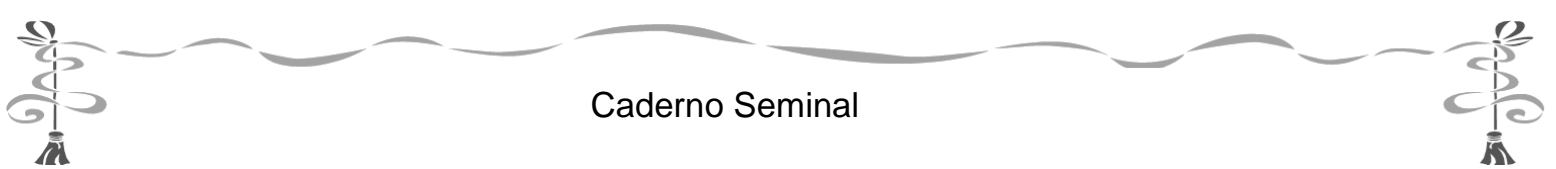

sua vez, estava subdividida em quatro fases, conforme pode ser observado na tabela abaixo.

\begin{tabular}{|c|c|c|c|}
\hline \multicolumn{3}{|c|}{ INSTRUMENTOS DE COLETA DE REGISTROS E GERAÇÃO DE DADOS } \\
\hline Participantes & Instrumentos & $\begin{array}{c}\text { Fases da } \\
\text { Investigação }\end{array}$ & Objetivos \\
\hline $\begin{array}{c}\text { Professora } \\
\text { mediadora e a } \\
\text { interagente } \\
\text { brasileira }\end{array}$ & Autobiografias e questionários & $1^{\text {a }}$ Fase & $\begin{array}{c}\text { Levantar as crenças entre } \\
\text { os participantes }\end{array}$ \\
\hline $\begin{array}{c}\text { Professora } \\
\text { Mediadora e a } \\
\text { interagente } \\
\text { brasileira }\end{array}$ & $\begin{array}{c}\text { Diários de pesquisa por parte da } \\
\text { interagente brasileira e do professor } \\
\text { mediador; gravação em áudio e } \\
\text { vídeo das interações em pares e } \\
\text { das interações professor mediador e } \\
\text { do seu respectivo interagente } \\
\text { brasileiro. }\end{array}$ & 2- Fase & $\begin{array}{c}\text { Analisar as crenças e } \\
\text { quais/como as } \\
\text { competências são (re) } \\
\text { construídas neste novo } \\
\text { contexto de ensino- } \\
\text { aprendizagem de línguas }\end{array}$ \\
$\begin{array}{c}\text { Professora } \\
\text { mediadora e os } \\
\text { interagentes } \\
\text { (brasileira e } \\
\text { estrangeiro) }\end{array}$ & $\begin{array}{c}\text { Gravações em áudio e vídeo das } \\
\text { interações entre a interagente } \\
\text { brasileira e a professora mediadora } \\
\text { e as sessões de interação com o } \\
\text { interagente estrangeiro. }\end{array}$ & 3- Fase & $\begin{array}{c}\text { Procuramos analisar os } \\
\text { reflexos que as ações } \\
\text { realizadas pela professora- } \\
\text { mediadora podem ter no } \\
\text { sistema de crenças do } \\
\text { interagente brasileiro. }\end{array}$ \\
\hline
\end{tabular}

\section{Análise de Dados}

Com o propósito de investigar se no processo de (trans) formação inicial, desenvolvido no projeto "Teletandem Brasil: Linguas Estrangeiras para Todos" com um professor mediador e os interagentes (brasileiro e o estrangeiro), ocorre legitimação de crenças e/ou (re) construção de competências, nos respaldaremos na seguinte pergunta de pesquisa: "Que reflexos as ações realizadas pela professora mediadora podem ter no sistema de crenças do interagente brasileiro?’. Para investigar esta questão, focalizaremos em duas sub-perguntas neste artigo: "O que acontece no trabalbo de mediação e/ on supervisão? A professora mediadora legitima as suas próprias crenças e/ ou cria condiçôes para a (re) construção de competências?.

\section{O acontece no trabalho de mediação?}

No processo de mediação, a professora mediadora, sempre possibilitou meios para a reflexão, conduzindo a interagente brasileira a refletir acerca do processo de aprender e de ensinar uma LE. O excerto abaixo assevera isto

A diferença, no entanto, creio que tenha sido no nível de reflexão que procurei promover, uma vez que houve pelo menos dois momentos em que a percebi que a Cláudia pareceu repensar" alguns eventos das interações, à luz dos questionamentos. (Excerto 01: Diário da Mediadora)

Caderno Seminal Digital Ano 18, nº 18, V. 18 (Jul-Dez/2012) - ISSN 1806-9142

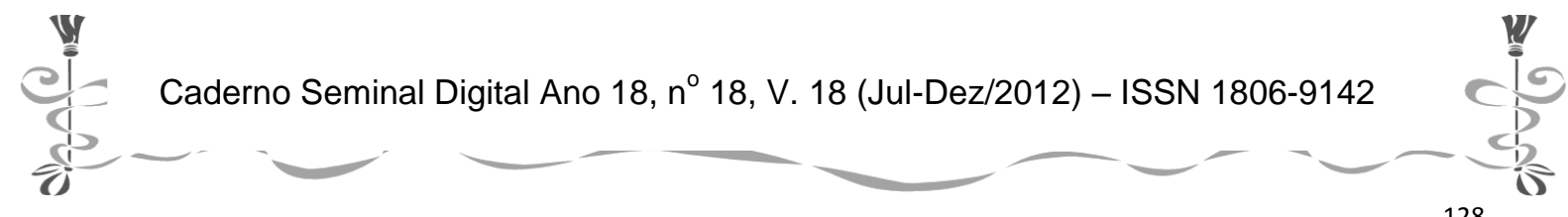




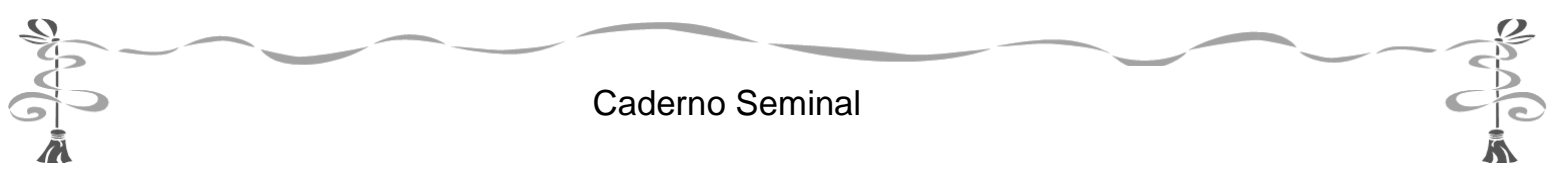

Este repensar, segundo a professora mediadora, está relacionado às estratégias que poderiam ser utilizadas pela interagente brasileira nas interações tanto em língua portuguesa quanto em LE (neste caso, Inglês), conforme pode ser observado nos excertos abaixo.

(...) Um dos momentos foi a respeito das interações em português: perguntei o que ela pretendia fazer para tentar ajudar o seu par interagente (doravante PI) a superar essa "dificuldade" que ela diz perceber durante as interações em português. Sugeri que ela pensasse em estratégias, on açooes pedagógicas concretas e ela diz que ainda não sabe o que fazer. Quando surgiu a ideia de proporem-se temas para que eles se preparassem antes das interações, ela diz que desconfia que seu PI pode não gostar, visto que em outros momentos em que a interação fica um pouco previsível, ele parece não gostar muito. Ainda creio que, do ponto de vista pedagógico, essa seria uma boa alternativa, pois, supõe-se que PI iria pesquisar, não só o vocabulário, mas outros aspectos linguísticos para falar sobre os temas definidos, e assim, haveria produção de insumo e, possivelmente, o feedback a essa produção. Porém, não sei até que ponto devo insistir nisso. Aliás, não tenho certeza se isso seria realmente eficaz e, por outro lado, Cláudia não parece ter outras ideias alternativas... Por esse motivo, sugeri que ela relesse todas as interações em português, com o objetivo de buscar possíveis alternativas para essa questão de ensino do português como língua estrangeira. (Excerto 02: Diário da Mediadora)

(...) O outro momento em que percebi certa reflexão foi quando falávamos sobre sen processo de aprendizagem e ela disse não ter certeza sobre quais aspectos ela deveria melhorar e ela afirmou não saber. Além disso, ela havia feito uma comparação entre a produção de PI em português e sua própria em inglês e afirmou que achava que PI usava a língua estrangeira melhor do que ela, pelo pouco tempo que ele diz estar estudando (5 semanas). Eu então perguntei quais aspectos de sua produção PI tem corrigido e ela disse que também ainda não havia prestado atenção nisso. Nesse momento ela pareceu perceber que, apesar de observar esses detalhes durante as interações em português, quando ela é a "professora", ela não estava fazendo o mesmo durante as interações em inglês, quando é aprendiz... Sugeri, então, que ela relesse as interações em inglês e tentasse perceber em que momentos ocorrem as correções, o que ela achou uma boa ideia. (Excerto 03: Diário da Mediadora)

Conforme podemos observar nos excertos 02 e 03, esta reflexão envolveria a utilização de estratégias ou ações pedagógicas concretas e uma reflexão concernente ao processo de aprender e ensinar línguas em que ambas estavam inseridas.

A abordagem utilizada pela mediadora está em consonância com a proposta por KORTHAGEN \& KESSELS (1999) e intitula-se "realista". Segundo os referidos autores e corroborado por Vieira-Abrahão (2009, p. 20), esta abordagem

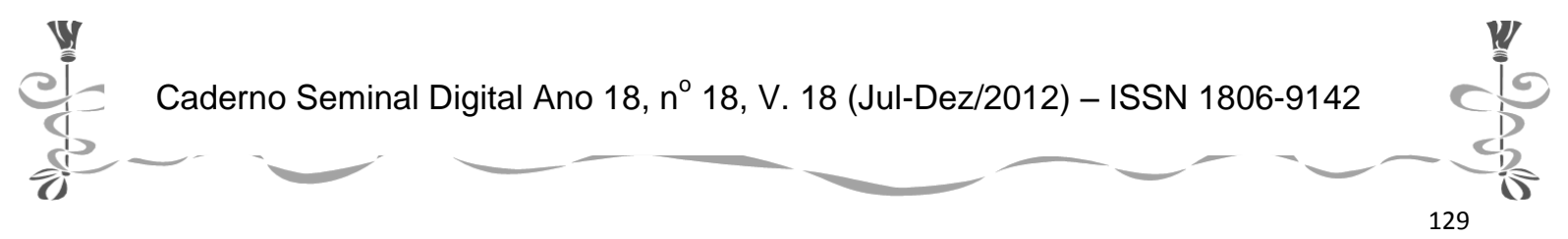




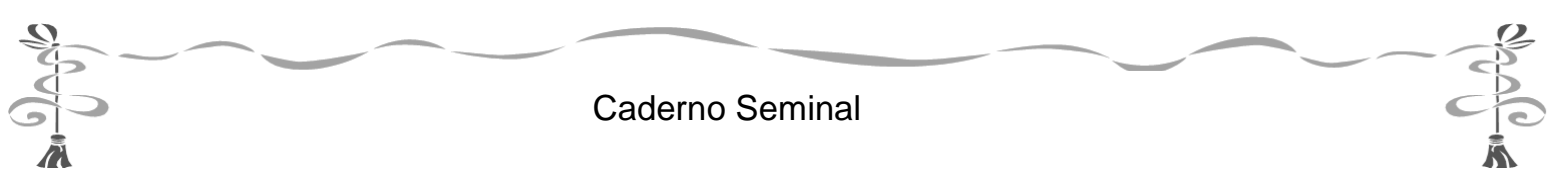

(...) prevê a integração teoria e prática de tal maneira que propicie a integração de ambas no interior do professor. Seu ponto de partida são problemas reais encontrados na prática de ensinar do professor e o conhecimento é construído (acrescentamos reconstruídos) por meio da reflexão sobre os problemas reais encontrados e por meio de teorias que se fazem necessárias para a compreensão e busca de soluções.

O excerto apresentado a seguir evidencia a (re) construção desta abordagem de ensino, evidenciando a (re) articulação entre os princípios teóricos advindos das discussões teóricas antes/durante as mediações e o oferecimento de textos teóricos para leitura e reflexão, com o intuito de "embasar a discussão e o planejamento de ações futuras", bem como aventar possíveis soluções para problemas ou questões envolvendo a linguagem que possam surgir.

Sueli: Eu não sei se é por ai que você fere o princípio da autonomia. O que eu entendi, eu vou te falar o que eu entendi durante a sua apresentação. Eu acho que o fato de você pretender no seu projeto induzir, não negociar, induzir determinadas...

Cláudia: Ah eu entendi também...

Sueli: Isso entra em conflito com o princípio da autonomia, a ideia de indução.

Cláudia: Hum hum.

Sueli: Que é diferente de negociação.

Cláudia: É, mas se isso é só uma tática que eu estou usando para ensinar para ele, o que ele já demonstrou estar precisando, entendeu? E não só isso, porque eu não posso ficar corrigindo todos os erros que ele produz em uma interação, né? Às vezes eu induzo ele a assim - ah como diz nananãl, e eu —ah como diz nananã?ll, eu não falo —ó ta errado é assimll.

Sueli: É uma reformulação.

Cláudia: Eu repito, não é uma forma de indução. Eu to induzindo ele a ver que aquilo que produziu é um erro.

Sueli: Ah entendi.

Cláudia: (risos)

Sueli: E você considera isso uma maneira de induzi-lo.

Cláudia: Hum hum. Eu estou induzindo ele a ver o que ele fez ta errado e...

Sueli: Você precisa colocar isso no seu ponto de vista, Cláudia. É uma maneira diferente de ver a indução.

Cláudia: Humhum.

Sueli: Nesse exemplo específico que você deu, por exemplo...

Cláudia: Porque eu faço muito isso.

Sueli: Porque isso, num sei, seria até interessante você ler, porque dentro das diferentes maneiras de fazer correção, essa é uma delas, ela chama reformulação.

Cláudia: Humhum.

Sueli: Em que você repete o que o aluno disse eliminando o erro, mas de uma maneira implícita.

Cláudia: Humhum.

Sueli: Você não está dizendo —ó, está errado, é assimll, você simplesmente refaz o enunciado, eliminando o erro e continua a interação, sem chamar a atenção para isso.

Cláudia: Humhum.

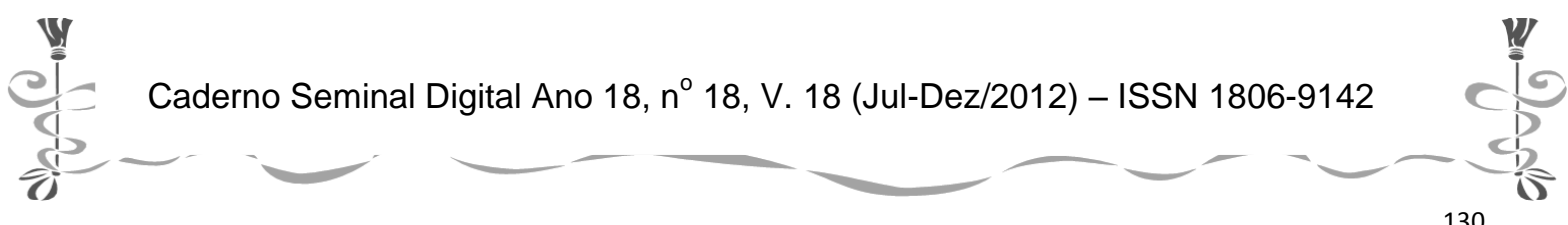




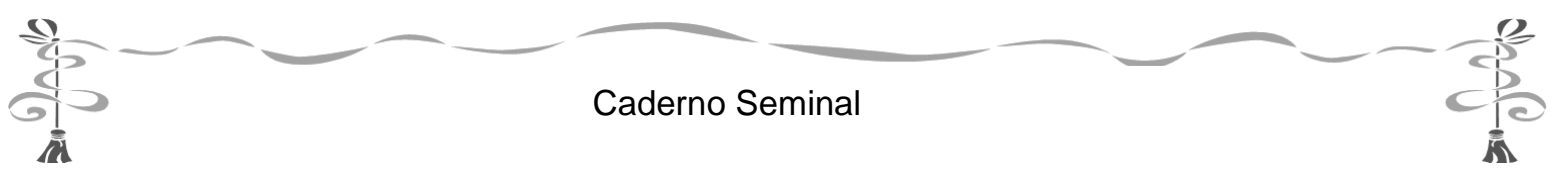

Sueli: Então isso se chama reformulação. Eu nunca havia pensado nisso como uma maneira de indução, nunca. Bom, aliás se eu pensar assim, todas as maneiras de correção são uma forma de indução. Pensa um pouco.

Cláudia: Todas?

Sueli: Eu não estou induzindo o outro a perceber de forma implícita ou explícita que tá errado, que eu considero aquilo como um erro? O certo seria uma outra forma? (mediação 3 entre Cláudia e Sueli). (Excerto 04: Diário da Mediadora)

Neste excerto, é possível observarmos um diálogo crítico-reflexivo entre a Cláudia (que desempenha o papel de aluna-professora) e Sueli (no papel de professora mediadora) sobre conceitos amplamente utilizados nas teorias de ensinoaprendizagem de línguas, a saber: autonomia, negociação, correção e/ou tratamento de erros de erros, reformulação e indução (Cavalari, 2009). A mediadora traz as questões da linguagem inseridas nesta prática social real (virtual), à luz dos princípios teóricos advindos da LA e/ou áreas afins. Por ter desenvolvido um estudo empírico de mestrado tendo como cerne as questões supracitadas, a professora mediadora tem um sólido embasamento teórico, procurando, de uma forma reflexiva, cooperativa e colaborativa, auxiliar a sua interagente a examinar e a refletir sobre suas ações, visto que a mesma ainda desconhece estes pressupostos teóricos visto que no momento quando foi coletado os registrados, a interagente brasileira se encontrava no processo de (trans) formação inicial de professores de línguas.

Algo que nos chamou muito a atenção na releitura e posterior análise dos dados, é a maneira como Sueli sugere a Cláudia que se (des) envolva nas interações e que mergulhe nas leituras teóricas da área. Estas ações, propiciarão que a mesma realize uma prática mais efetiva e possa estar preparada para as futuras interações com o estrangeiro estadunidense, articulando as teorias advindas da literatura com as suas próprias e as teorias implícitas do estrangeiro. Neste caminho é possível depreendermos o desenvolvimento e/ou (re) construção de duas competências: a) a teórica, que segundo Vieira-Abrahão (1996), envolve saber explicar porque ensina da forma que ensina, e porque os alunos aprendem da forma que aprendem (estratégias e estilos de aprendizagem; inteligência múltiplas, dentre outros), ao passo que fizermos isto estaremos desenvolvendo aquilo que Prabhu (1990) denominada como senso de plausibilidade ${ }^{68}$; b) a aplicada, vivenciada e/ ou sintética, que envolve, segundo Almeida Filho (1993), o professor explicar “(...) com plausibilidade por que ensina como ensina da maneira como ensina e porque obtém os resultados que obtém”.

Sem dúvida, a nosso ver e corroborado por outros excertos extraídos, a professora mediadora possibilita meios para que a interagente possa refletir sobre o processo de ensino e aprendizagem de línguas, mostrando que as ações empreendidas pela mesma nas sessões de mediação não são formas de apenas legitimar as suas próprias crenças, mas de possibilitar condições para que a interagente (re)construa as

${ }^{68}$ Para maiores informações sobre o "senso de plausibilidade" do professor de línguas, veja Sandei (2007).

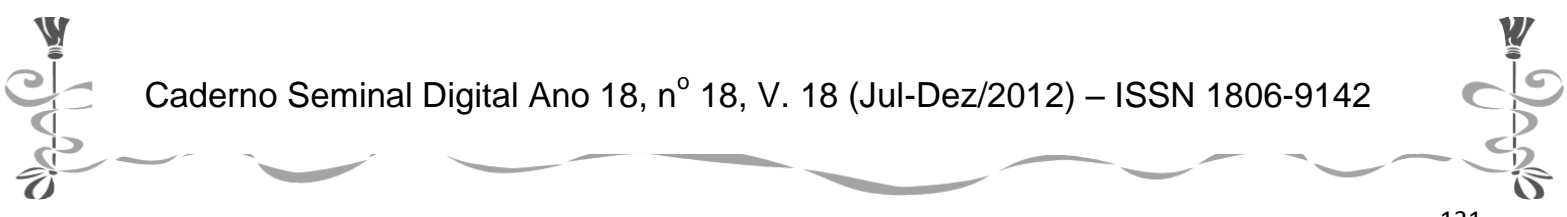




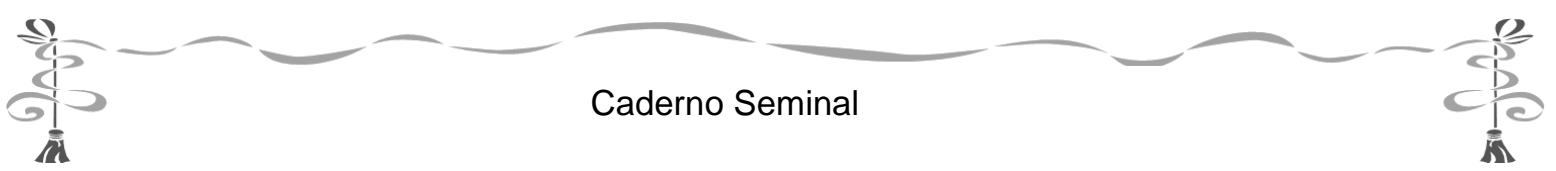

competências (teórica e aplicada/sintética e vivenciada) e pense criticamente acerca do seu papel como professora ou como aprendiz de línguas.

\section{A professora mediadora: Legitima as suas próprias crenças e/ou (re)constrói competências?}

Conforme já apresentado e discutido na seção anterior, a professora cria condições para a (re) construção de competências para o meio virtual. Por esta razão, apresentaremos nesta seção algumas competências ${ }^{69}$ que emergiram ou que foram (re) construídas nas sessões de mediação e os possíveis reflexos das mesmas nas interações do interagente brasileiro com o estrangeiro.

\section{A Competência Implícita}

Corroboramos com ALMEIDA FILHO (1993) quando afirma que a "competência implícita" é constituída de "crenças e intuições", que são geralmente influenciadas por nossas experiências vividas, assim como pela tradição cultural de seu país ou etnia. Geralmente esta competência implícita, na maioria das vezes, não é conhecida pelo professor de língua em (trans) formação inicial e/ou contínua. O (re) conhecimento desta competência se dá, convergindo com diversos estudiosos da LA (VIEIRA-ABRAHÃO, 2009, 2004; ALMEIDA FLHO, 2006; SILVA, ROCHA \& SANDEI, 2005; dentre outros), por meio de diários reflexivos, sessões de visionamento, revisitação vicária e/ou outros procedimentos que poderiam ser utilizados advindos da prática crítico-reflexiva (SILVA, ROCHA \& SANDEI, 2005).

Por se tratar de um estudo empírico de doutorado, realizamos, dentre outras coisas, o levantamento de quatro categorizas de crenças a partir dos instrumentos de coleta de registros apresentados preliminarmente (questionários e autobiografias), incluindo as suas respectivas subcategorias diversas, a saber: a) o contexto de ensino $e$ aprendizagem de línguas; b) concep̧ões de escola pública/particular, c) experiências de ensino vivenciadas pelos participantes; d) convergências e/ ou divergências das crenças entre os participantes e suas possiveis origens.

Tendo como escopo teórico os estudos sobre crenças realizados no Brasil e no exterior (KALAJA, PAIVA \& BARCELOS, 2008; BARCELOS, 2007; BARCELOS \& VIEIRA-ABRAHÃO, 2006; KALAJA \& BARCELOS, 2005), e principalmente, o contexto inovador de ensino-aprendizagem e de (trans) formação de professores de línguas, concebemos crenças, sob um viés bakhtiniano, como os diferentes modos, axiologicamente (leia-se ideologicamente) constituídos, de se atribuir sentido(s) ao mundo, refletindo-o e, também, refratando-o. São, portanto, dialogicamente constituídas pela diversidade e pelos conflitos, assumindo um caráter

\footnotetext{
${ }^{69}$ Por uma questão de espaço, não serão apresentadas todas as competências que emergiram no nosso estudo empírico. Em outro artigo e na tese, que se encontra em desenvolvimento, serão apresentadas as mesmas.
}

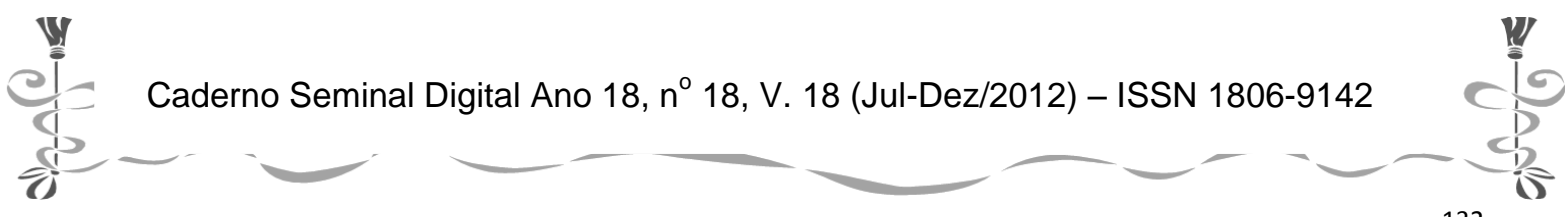




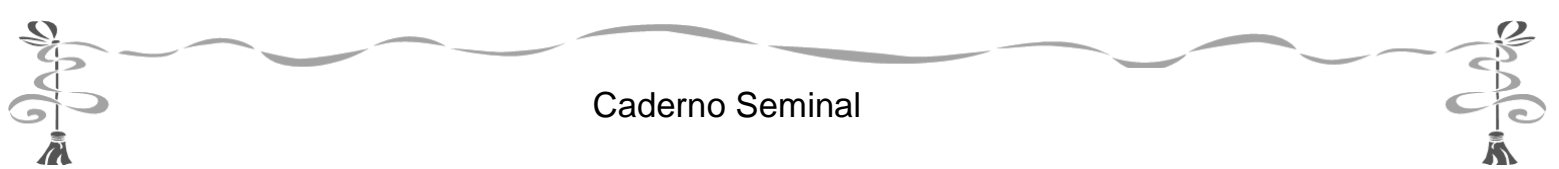

multissêmico, em uma sociedade marcada, por sua vez, pelas contradições e confrontos de interesses e valores (cf. Faraco, 2006).

Neste sentido, as quatro categorias de crenças já identificadas neste estudo podem ser definidas abaixo, por meio dos aspectos aos quais se relacionam:

a) O contexto de ensino e aprendizagem de linguas: Esta categoria refere-se as primeiras experiências de escolarização; os primeiros contatos com o ensino de línguas advindos da experiência da escola pública e/ou particular de ensino, conforme pode ser observado nos excertos apresentados a seguir:

Eu tinha 5 (quase 6) anos quando fui a escola pela primeira vez - uma pré-escola da prefeitura, perto de casa. Não fui alfabetizada antes da primeira série, portando, só aprendi as primeiras letras aos 7 anos de idade, na Escola Estadual Cenobelino de Barros Serra. (Excerto 05: Mediadora - Autobiografia)

Minha primeira experiência escolar foi aos 3 anos de idade, em uma escolinha da prefeitura no bairro em que moro. Estudei neste local por dois anos e tenho a lembrança de ter sido encarregada de fazer um desenho sobre o Natal que seria exposto na Biblioteca Municipal, o que me motivou muito a realizar tal atividade. Quando eu estava com 5 anos, quase completando 6 , meus pais conseguiram uma vaga para que eu estudasse na pré-escola de uma escola muito bem conceituada na época: o Centro Educacional SESI 410, onde permaneci até a oitava série. Lembro-me que tive uma boa relação com a professora do pré, tanto que o contato com ela continuou por muito tempo depois de eu ter terminado aquela série. Quando cheguei à primeira série, eu já estava alfabetizada e, por isso, não encontrei muitas dificuldades. Eu fui uma boa aluna, tanto por cobrança dos meus pais quanto minha mesmo - eu adorava quando a professora escrevia um "Parabéns" no meu caderno e colocava três estrelinhas! Um aspecto muito positivo desta escola era que desde cedo fui incentivada à leitura. Lembro-me que, na segunda série, inscrevi-me em um concurso de redação (interno mesmo, só para as segundas séries) que tinha como prêmio um livro e, para minha satisfação, acabei vencendo tal concurso. (Excerto 06: Interagente Autobiografia)

b) Concep̧cões de escola pública/particular e as experiências vivenciadas pelos participantes nos referidos contextos: Tanto a professora mediadora quanto a interagente tiveram experiências no ensino de línguas no contexto da escola pública e particular de ensino. Porém, conforme pode se observar nos excertos abaixo, as suas visões e concepções sobre os referidos contextos divergem, e as variáveis que justificam a referida divergência serão explicitadas nas próximas subseções.

(...) Minha lembrança da escola pública, é de um ambiente de muita descontração, onde eu me sentia completamente a vontade - às vezes, fazia os exercícios no colo da professora e, normalmente, no final da aula, eu e minhas amigas (que vieram da pré-escola) tínhamos permissão

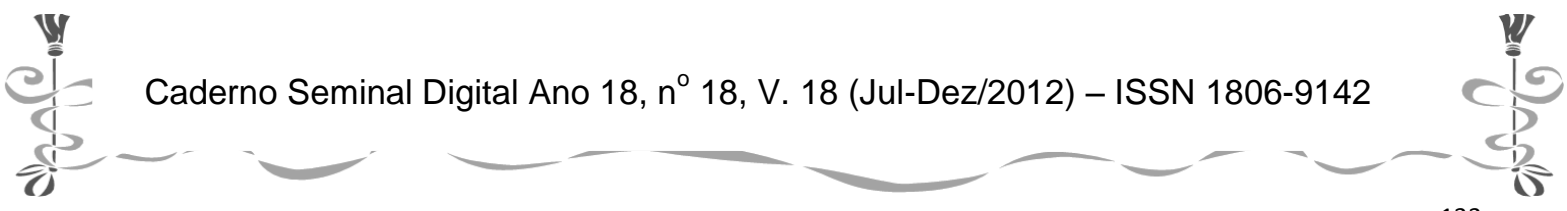




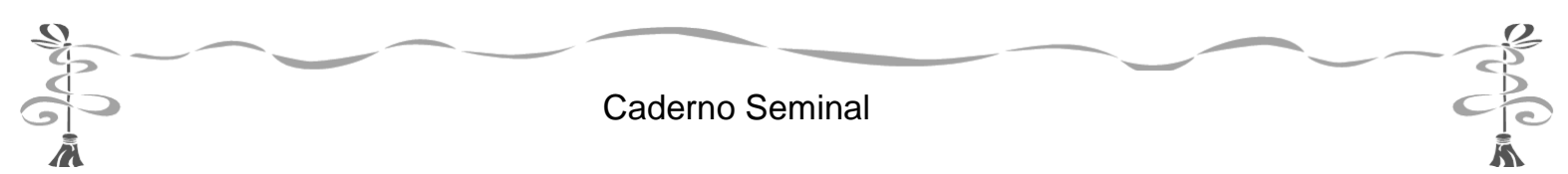

para cantarmos nossas músicas preferidas na frente da classe. No colégio particular, por sua vez, a professora da segunda série mais parecia um general militar, pois tinha uma visão de disciplina extremamente rígida. A verdade é que eu não conseguia entender certas exigências que ela fazia: as carteiras deveriam estar sempre rigorosamente alinhadas; os lápis (todos!, inclusive os de cor) deveriam ser apontados em casa e não deveríamos trazer o apontador para a sala de aula - e nem usar lapiseira; não podíamos nos levantar da carteira, nem ir ao banheiro durante a aula - enfim, havia uma série de novas regras às quais tive que me adaptar a duras penas, pois foi um período muito difícil. (Excerto 07: Mediadora Autobiografia)

As regras de disciplina daquela escola na época para o primeiro ciclo do Ensino Fundamental (primeira a quarta série) eram muito rígidas: para sairmos para o recreio tínhamos de fazer fila por ordem de tamanho e chegar ao pátio em fila; quando dava o sinal para retornarmos à sala de aula, também deveríamos fazer fila e, antes de entrarmos, cantávamos algumas músicas (estas que se ensinam às crianças na escola); todos os alunos deviam estar uniformizados para assistirem aula, tanto que no começo do ano éramos obrigados a comprar duas trocas do uniforme - $\mathrm{O}$ não cumprimento dessa norma acarretava em, no mínimo, uma carta de advertência aos pais; todos os cadernos e livros tinham de ser encapados com papel verniz azul marinho; nossas carteiras deveriam estar sempre alinhadas e nunca encostadas na parede. Contudo, nunca encontrei dificuldades em atender a estas exigências, pelo contrário, eu fazia de tudo para nunca levar uma advertência, pois para mim isso era muito feio para uma menina. Devo salientar que meus pais nunca foram autoritários comigo, ou seja, eles cobravam que eu estudasse para ser alguém na vida, não que eu fosse a melhor aluna da sala. No entanto, desenvolvi, acredito que por mim mesmo, este comportamento conservador. (Excerto 08: Interagente - Autobiografia)

Esta incongruência e/ou divergência de visões/concepções sobre o contexto das escolas da rede (pública e particular) de ensino deve-se a especificidades que engendram cada contexto. Conforme já corroborado em outros estudos (Coelho, 2005; Silva, 2005; Barcelos, 1995), muitos acreditam que não se aprende inglếs na escola pública (cf. Coelho, 2005). Porém, ainda há alguns nichos públicos de ensino que ainda gozam de prestígio (escolas técnicas, Sesi, etc.).

Ou seja, muitos acreditam que é possível ensinar-aprender línguas neste contexto, e não no contexto "tradicional" de ensino público. Certamente há inúmeros fatores que poderiam dificultar o ensino efetivo de LEs nas escolas públicas de ensino: salas de aula superlotadas; infraestrutura inadequada; livros didáticos, dentre outros. Porém, a nosso ver, precisamos pensar em mecanismos para a superação destas mazelas que certamente dificultam mas não impossibilitam o processo de ensino e de aprendizagem de LEs.

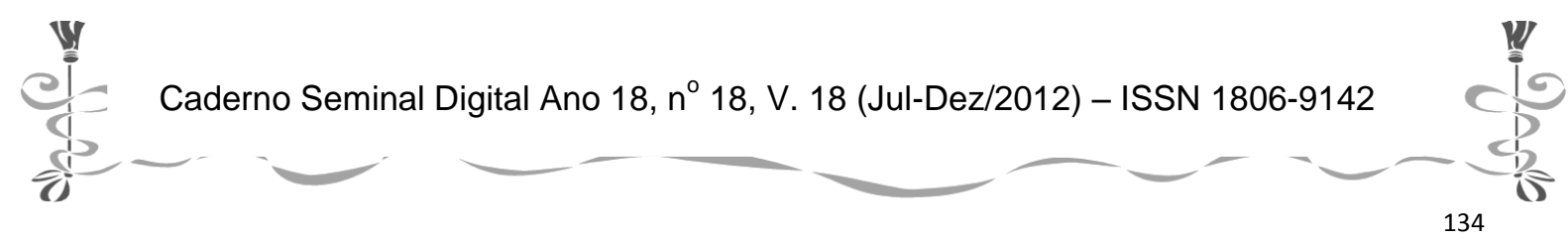




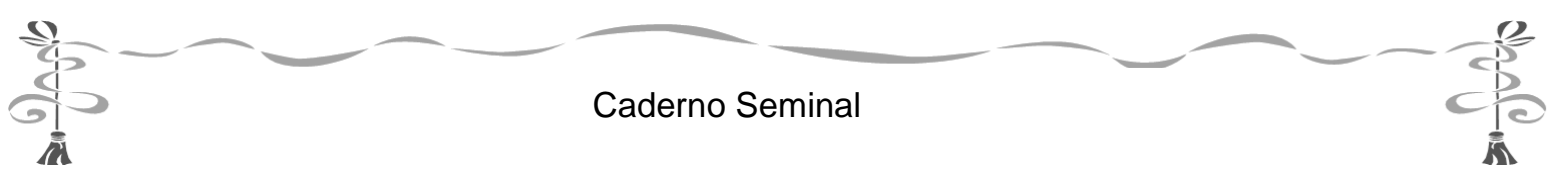

Corroboramos com Paiva (1997, p. 9) quando afirma que o professor de línguas "(...) deveria ter, além de consciência política, bom domínio do idioma (oral e escrito) e sólida formação pedagógica com aprofundamento em Linguística Aplicada". Este "domínio do idioma (oral e escrito)", envolve aquilo que concebemos como "competência linguística comunicativa", experiência na e sobre a língua alvo e a "formação pedagógica com aprofundamento em LA" seria aquilo que Almeida Filho (1993) pontuava como "competência teórica".

Este protótipo prefigurado por Paiva (1997), que deveria fazer parte da nossa "realidade", está apenas no âmbito "ideal", e é reduzido em nossa sociedade. Por esta razão, a nosso ver, é necessária uma transformação e/ou metamorfose das políticas de formação de professores de línguas no contexto brasileiro.

c) Convergências e/ ou divergências das crenças entre os participantes e suas possiveis origens: Os participantes de nossa pesquisa em muitos momentos apresentam convergências no seu sistema de crenças. Hipotetizamos que isto se deve ao processo de (trans) formação inicial e/ou contínua em que ambas as participantes estão inseridas (graduação no caso da interangente e de pós-graduação no caso da professora mediadora) e que se respaldam, por sua vez, nos paradigmas de uma prática críticoreflexiva, conforme pode ser observado em Vieira-Abrahão (2006), e no sítio eletrônico da instituição.

\footnotetext{
"O trabalho de formação inicial (...) fundamenta-se na perspectiva de aprendizagem docente como cognição, como construção de conhecimentos, mais especificamente em uma concepção sociointeracional, e como prática reflexiva" ${ }^{70}$.

“(...) O objetivo principal é formar docentes que atuem no ensino superior e pesquisadores capazes de contribuir para as áreas de concentração contempladas" ${ }^{71}$.
}

Por os pesquisadores da linguagem que estão imbricados dentro deste nicho acadêmico-científico (formação inicial e/ou contínua) e que tem os pressupostos teóricos e práticos da reflexão, observamos que este discurso não se encontra apenas no "dizer", mas também no "fazer" acadêmico.

\footnotetext{
${ }^{70}$ Para maiores informações sobre a filosofia que interfaceia os cursos de formação inicial da UNESP (São José do Rio Preto), Universidade Estadual de Londrina (UEL), Pontifícia Universidade Católica de São Paulo (PUC-SP) e Universidade Federal de Minas Gerais (UFMG), veja Vieira-Abrahão,

${ }^{71}$ As áreas de concentração do programa Stricto Sensu em "Estudos Linguísticos” (Mestrado e Doutorado), a saber: a) “Análise Linguística", com seis linhas de pesquisa (descrição e análise das línguas de especialidade; descrição funcional de língua oral e escrita; estudos do texto e do discurso; oralidade e letramento; tratamento do léxico da língua geral; variação e mudança linguística); b) "LA", com duas linhas de pesquisa (ensino e aprendizagem de Línguas - linha de pesquisa em que a professora mediadora desenvolveu o seu estudo e nicho aonde esta tese de doutorado se inseriu; e estudos da tradução).
}

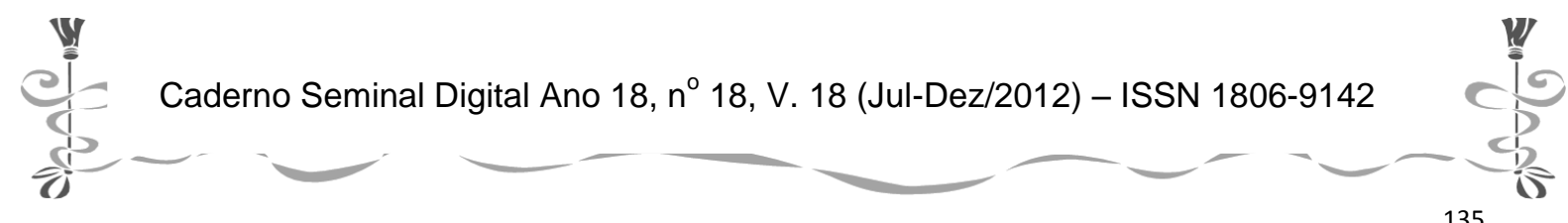




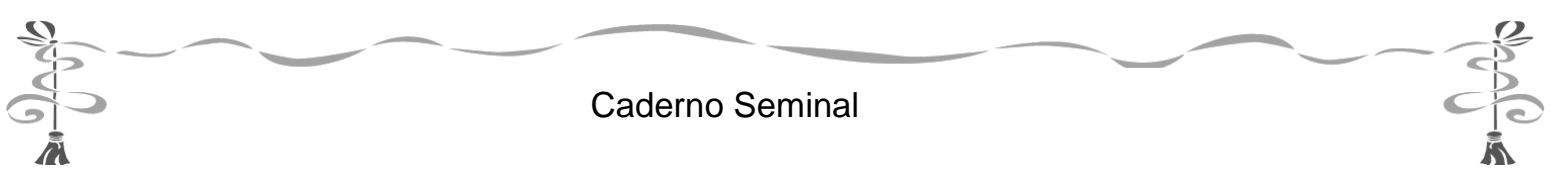

Quanto às origens das crenças, Vieira-Abrahão (2004, p. 147) assevera que, "mapear com exatidão as origens das crenças trazidas pelos alunos professores de línguas" é uma missão "difícil senão impossível". Levando em consideração esta premissa, o que pretendemos apresentar nesta subseção são hipóteses baseadas nos fatos, reflexões das histórias de vida de cada participante para se ter uma visão mais ampla destas origens.

A análise evidenciou que a professora mediadora, antes de iniciar a sua formação em LA por meio dos cursos de pós-graduação Stricto Sensu (Mestrado e Doutorado), tinha a sua prática pedagógica como professora de língua inglesa respalda em: a) sua experiência como aluna (cultura de aprender); b) treinamentos semestrais dados pela escola de língua que trabalhava (cultura de terceiros) e; c) pelos congressos da área que participava; conforme pode ser observado no excerto 09:

“(...) por minha experiência como aluna, especialmente como aluna de língua estrangeira; pelos treinamentos semestrais dados por essa escola, onde trabalhei por 6 anos; pelos congressos para professores dos quais passei a participar periodicamente". (Excerto 09: Autobiografia da Professora Mediadora)

A partir deste excerto podemos hipotetizar que grande parte das crenças dessa professora mediadora teve como gênesis a sua experiência como aprendiz, como professora de escola de línguas e do processo de formação na pós-graduação que certamente contribuiu expressivamente para a (re) construção do seu sistema de crenças.

No que tange a interagente brasileira, as suas crenças sobre o ensino e aprendizagem de línguas advém da sua experiência como aluna (observe os excertos 10 e 11) e do processo de (trans) formação inicial de professores que está inserida no momento (excerto 12), conforme pode ser observado nos excertos abaixo e no diagrama abaixo.

(...) De maneira geral, acredito que tive uma boa formação no segundo ciclo do Ensino Fundamental em todas as disciplinas, exceto com relação ao inglês. As professoras que tive trabalhavam muito superficialmente o conteúdo e sempre fazendo traduções de tudo que estava na lousa ou livro, não exploravam todas as habilidades, somente a escrita e, mesmo assim, apenas fazendo exercícios de lacuna presentes no livro didático. Acredito que isso contribuiu para que eu não percebesse uma função prática no que eu estava aprendendo, fazendo com que eu me desinteressasse completamente por esta disciplina, ou seja, eu estudava bastante e fazia as atividades pedidas somente para garantir a minha nota. (Excerto 10: Autobiografia da Interagente Brasileira)

(...) não tive uma boa formação com relação ao inglês e, sendo assim, a disciplina de Língua Inglesa na faculdade é a que exigiu e ainda exige

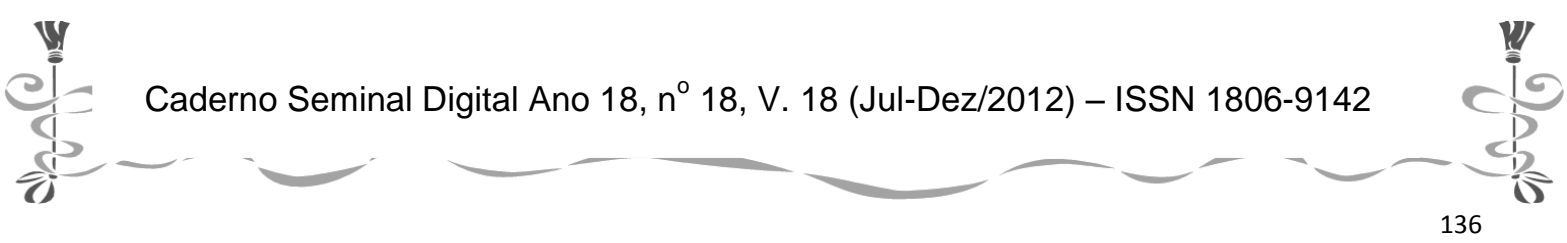




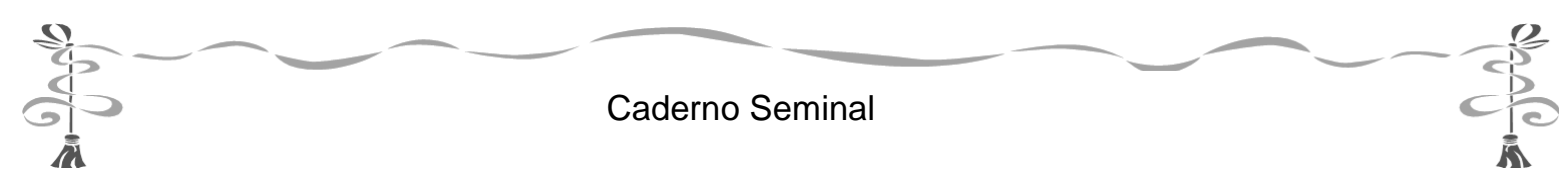

meus maiores esforços para se obter progresso. (Excerto 11: Autobiografia da Interagente Brasileira)

(...) O estímulo para eu pensar em um projeto de Iniciação Científica veio quando eu entrei em contato com o Teletandem Brasil, agora no quarto ano. Com este projeto eu pude esboçar uma pesquisa que tratasse de algo que sempre me chamou a atenção desde o segundo ano da graduação, após ter tido um breve contato com tal assunto em uma aula: o ensino de língua portuguesa para estrangeiros. Sinto que, finalmente, encontrei o que eu estava procurando, pois estou adorando refletir sobre as dificuldades encontradas por um estrangeiro (no caso da minha pesquisa um americano), em aprender a língua portuguesa. Tal experiência também motivou-me a pensar a respeito de um projeto de mestrado. Este ano, estou cursando as disciplinas de Prática de Ensino em Língua Materna e Estrangeira, para as quais tive de fazer estágios de observação e elaborar minicursos. (Excerto 12: Autobiografia da Interagente Brasileira)

É digno de nota que, a interagente brasileira teve como possível gênesis de suas crenças a sua cultura de aprender e a cultura de aprender a ensinar línguas, enquanto que a professora mediadora teve como gênesis a sua cultura de aprender, cultura de terceiros e cultura de aprender a ensinar línguas.

A nosso ver, é necessário que os cursos de (trans) formação inicial propiciem aos futuros professores de línguas subsídios teóricos, práticos e metodológicos concernentes a como os nossos alunos aprendem uma LE. Em outras palavras, é necessário que desmistifiquemos a cultura de aprender línguas deles, a partir disto, de uma forma cooperativa/colaborativa e/ou autônoma, eles poderão desenvolver uma abordagem crítica-reflexiva.

\section{Teórica e Aplicada/Reflexiva/Vivenciada}

Para ALMEIDA FILHO (1993, p. 37) a competência teórica se refere ao conhecimento que vamos (re) construindo “(...) nos escritos, nos resultados de pesquisa de outros e que o professor já articula, de maneira que aquilo que ele faz vai ficando mais próximo daquilo que se sabe, que leu e que já sabe articular". Enquanto que, para VIEIRA-ABRAHÃO (1996) a competência teórica é considerada uma sub-competência aplicada, reflexiva e/ou vivenciada (BASSO, 2001), pois oferece explicações para o saber ensinar e o saber aprender.

A competência aplicada, por sua vez, é concebida como “(...) aquela que capacita o professor a ensinar de acordo com o que sabe conscientemente (sub-competência teórica) permitindo a ele explicar com plausibilidade por que ensina como ensina da maneira como ensina e porque obtém os resultados que obtém" (ALMEIDA FILHO, 1993, p. 37 - Ênfase adicionada).

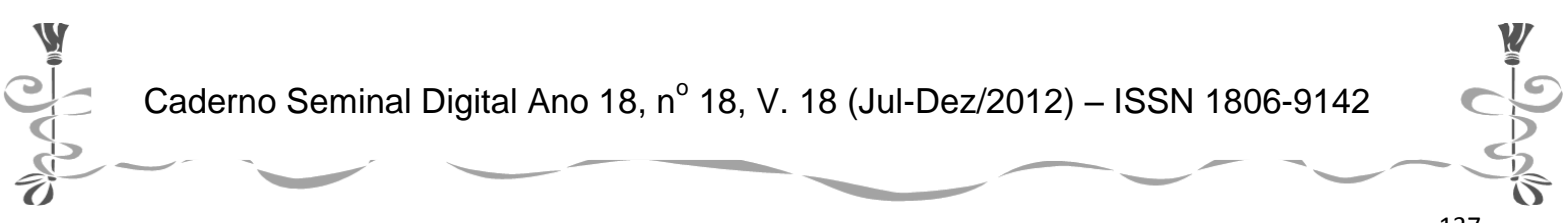




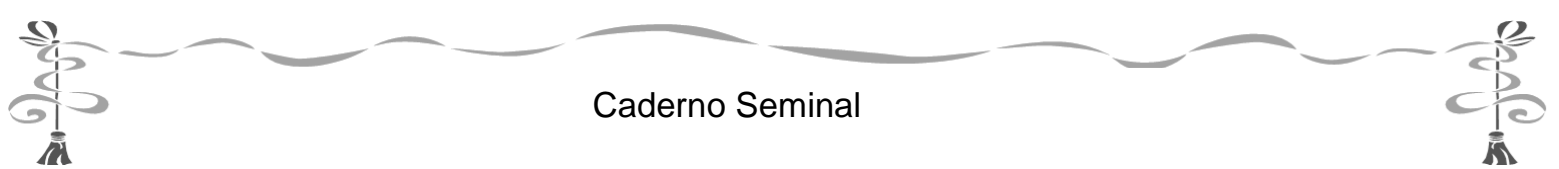

Tendo estes aportes teóricos como alusão e/ou pano de fundo, apresentaremos a seguir excertos que mostram possíveis reflexos da competência teórica e o articular da mesma tendo o meio onde a professora mediadora e a interagente brasileira estão inseridas e/ou imbricadas. Segundo os registros extraídos de sua autobiografia, a professora mediadora teve o "despertar" pela docência no ensino de línguas quando começou a ministrar aulas para crianças e adolescentes. A partir deste momento, ela decidiu se engajar na docência de línguas e através desta atuação se sentia realizada (fatores afetivos e/ou motivacionais).

No segundo ano de faculdade, surgiu uma oportunidade para que eu começasse a dar aulas de inglês: uma de minhas ex-professoras havia aberto sua própria escola de línguas e me convidou pra fazer um treinamento seletivo de professores. Comecei a dar aulas para crianças $e$ adolescentes e, nesse momento, percebi que jamais seria tradutora. O trabalho do tradutor, apesar de desafiador, é muito solitário e minha experiência como professora de línguas me mostrou que o contato com as pessoas e a interação com os alunos eram extremamente importantes para mim - eu me sentia plenamente realizada na sala de aula. Eu me esforçava muito para aprender a ensinar e tentava sempre me colocar no lugar do meu aluno, o que deve ter sido uma boa estratégia - os alunos pareciam gostar das minhas aulas e, a cada semestre, eu tinha mais turmas, de níveis cada vez mais avançados. (Excerto 13: Mediadora - Autobiografia)

Agora, tendo como foco o processo de mediação entre a Sueli e Cláudia, fica evidente a postura não diretiva, colaborativa e autoexploratória da professora mediadora, visto que ela não impõe, mas sugere procedimentos que poderiam ser utilizados pela interagente brasileira a fim de lidar com uma questão levantada pelo interagente estrangeiro.

Suely: E eu percebi que você tem, num é nem questão de você corrigir, é que às vezes é muito difícil de entender. Eu percebo que você negocia isso com ele assim né?

Cláudia: Aham.

Suely: Então. E percebendo que isso é um dos problemas, você imagina uma 25 maneira de tentar ajudá-lo com relação a isso?

Cláudia: Primeiro de tudo que eu penso com relação a isso e não falar assim diretão -O que que você quis dizer com isso? \| ou coisa assim direto que eu acho que inibe muito.

Suely: Hum hum.

Cláudia: Então eu pergunto algo mais sutil, sem perguntar de uma maneira bem /?/

Suely: Não, eu acho que é uma maneira assim, quando atrapalha a comunicação. Muitas vezes num tem como você ser sutil.

Cláudia: É que muitas vezes você fala assim —Que?\|.Né? É uma coisa assim meio chata.

Suely: Aham.

Cláudia: Eu acho -O que você quis dizer com tal palavra? \|

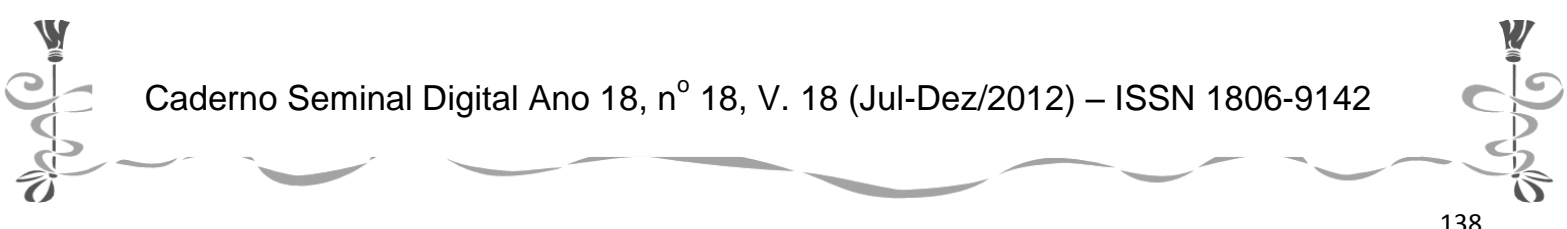




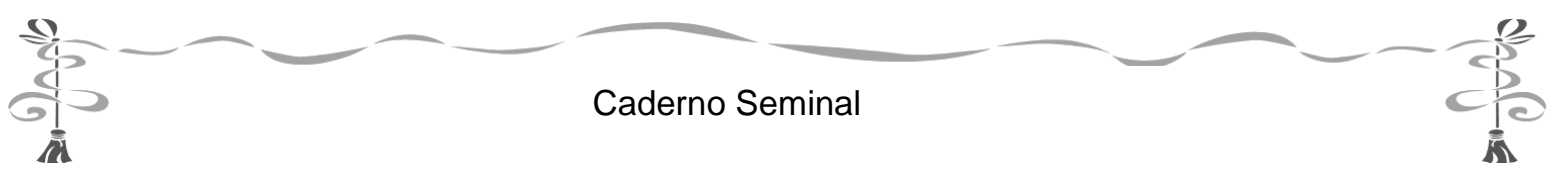

Suely: Exatamente.

Cláudia: Coisa mais./?/

Suely: Aham, eu percebo que você...

Cláudia: Mas com relação a uma estratégia concreta para eu ajudar a ele quanto a isso eu num sei. Acho que depende mais do momento, num sei.

Suely: Acho que seria interessante você pensar sabe, eu também assim, eu gostaria que você tentasse levantar algumas possibilidades entendeu? Tentar realmente em como, que tipo de atividade, ou que tipo de estratégia, enfim, como professora de língua estrangeira, o que você pode fazer para ajudá-lo a

desenvolver melhor essa questão de adequação. Eu acho que realmente parece ser um ponto importante...

(Excerto 14: Segunda interação entre a mediadora e a interagente brasileira)

Fica evidenciado neste excerto que a mediadora sugere e conduz a interagente brasileira a refletir sobre a questão. Este procedimento, a nosso ver, evidencia o articular dos princípios teóricos que ela já abarca advindo do processo de formação inicial e contínua e o a prática social real em que esteja inserida. Reiteramos que, na leitura dos dados, percebe-se em vários momentos que a referida mediadora, por ter um senso de plausibilidade acoplado com uma competência teórica, sabe explicar porque ensina da forma que ensina, nos mostrando que já tem desenvolvido uma competência aplicada (Almeida Filho, 1993) e/ou reflexiva (Basso, 2001).

\section{Competência Intercultural}

Para Kramsch (1993), e corroborado por Mendes (2007, p. 120), a competência intercultural se refere aos

(...) modos de compreender o 'outro' e a sua linguagem nacional.

(...) processo de comunicação entre pessoas que falam a mesma língua e compartilham um mesmo território, mas que participam de diferentes grupos culturais, como étnicos, sociais, de gênero, sexuais, etc. Então, pode designar as interações comunicativas entre indivíduos de classes sociais diferentes, grupos profissionais diferentes, entre gays e heterossexuais, entre homens e mulheres.

(...) pode também se referir ao diálogo entre culturas minoritárias e culturas dominantes, sendo também associado com situações de bilingualismo $e$ biculturalismo. (Ênfase adicionada)

Sob esta perspectiva, analisaremos agora o excerto 15 e vejamos os pressupostos teóricos apresentados preliminarmente e as sugestões dadas pela professora mediadora, que na perspectiva da interagente brasileira não seria eficaz, conforme pode ser observado a seguir

(...) Quando surgiu a ideia de proporem-se temas para que eles se preparassem antes das interações, ela diz que desconfia que seu par interagente (doravante PI) pode não gostar, visto que em outros

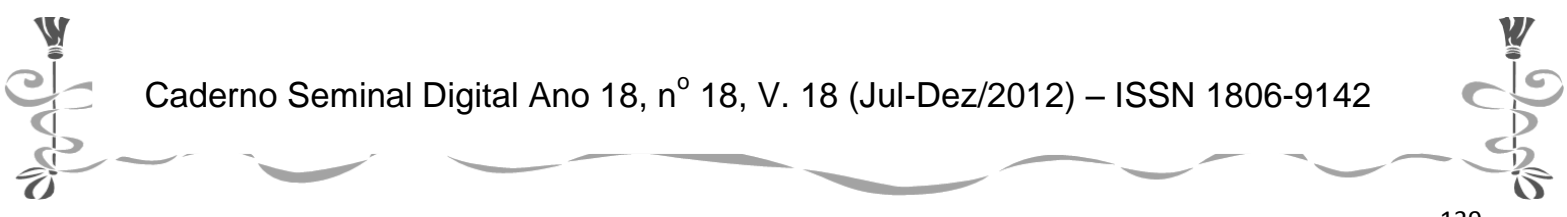




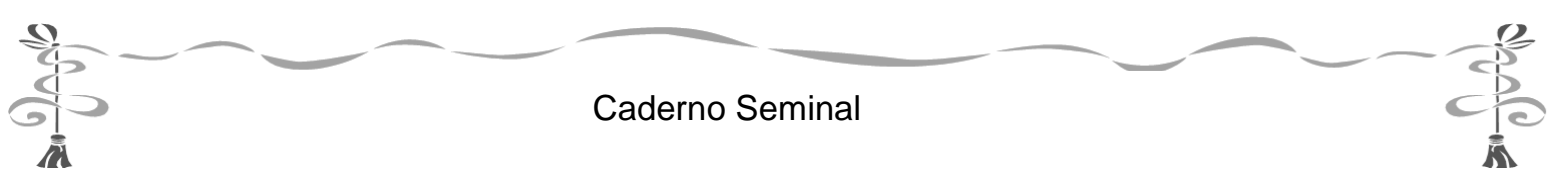

momentos em que a interação fica um pouco previsível, ele parece não gostar muito. Ainda creio que, do ponto de vista pedagógico, essa seria uma boa alternativa, pois, supõe-se que PI iria pesquisar, não só o vocabulário, mas outros aspectos linguísticos para falar sobre os temas definidos, e assim, haveria produção de insumo e, possivelmente, o feedback a essa produção. Porém, não sei até que ponto devo insistir nisso. Aliás, não tenho certeza se isso seria realmente eficaz e, por outro lado, Cláudia não parece ter outras ideias alternativas.

(Excerto 15: Diário da Interagente Brasileira)

Acreditamos que esta desconfiança deve-se a dois fatores. O primeiro, medo de perder o interagente americano, visto que a referida participante já passara por esta experiência. $\mathrm{E}$, o segundo, acredita que deva atender as necessidades comunicativas do outro.

No que concerne ao primeiro fator, o medo de perder o interagente brasileiro, observe o que ocorreu na segunda interação, conforme pode ser observado na interação e no diário da interagente.

Cody: qual sao os estereotipos das personas estadounidenses?

Cláudia: pessoas

Cody : sim....heha

Cláudia: bom... eu penso que são mais sérias

Cody : NAO!

Cláudia: hahahaha

Cláudia: não quis ofender

Cody entendo.

Cody entendo, pero não estou de acordo

Cody concordo?

Cody não concordo...?

Cláudia pero $=$ mas

Cody haha. mas não concordo.

Cody perfeito?

Cláudia eu não tenho uma opinião formada, pois nunca estive aí e não conheço nenhum americano pessoalmente.

(Excerto 16: Interação entre a Brasileira e o Estrangeiro)

(...) quando ele me perguntou qual era o estereótipo de uma pessoa estadunidense. Me senti desconfortável em responder isso, pois o que eu pensava de uma pessoa estadunidense é que se tratavam de pessoas sérias, não muito receptivas, ou seja, eu tinha uma imagem negativa. $\mathrm{O}$ melhor termo que encontrei para dizer a ele o que eu pensava sem ofendê-lo foi "sério". Mesmo assim, a resposta dele foi um não em letras maiúsculas, o que me deixou assustada. Entretanto, não ficou um clima ruim. Eu pedi desculpa, dizendo que não queria tê-lo ofendido; ele respondeu dizendo que não concordava com esta minha opinião, e depois continuamos a conversar, já sobre outro assunto muito mais agradável. (Excerto 17: Diário da Interagente Brasileira)

Caderno Seminal Digital Ano 18, n 18, V. 18 (Jul-Dez/2012) - ISSN 1806-9142

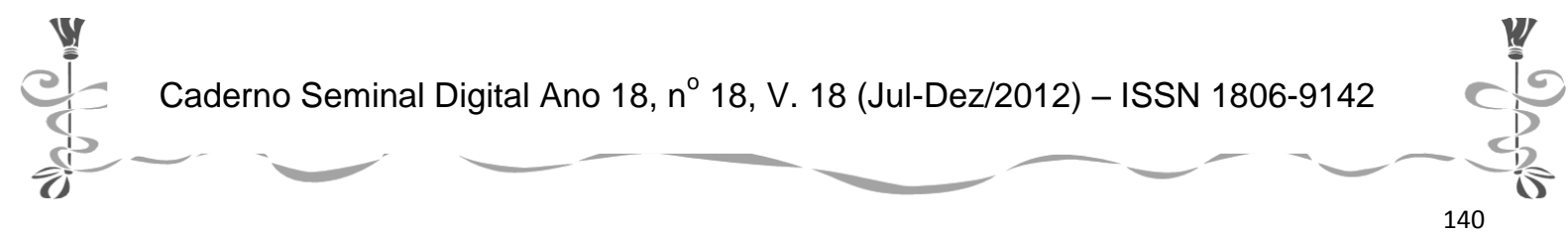




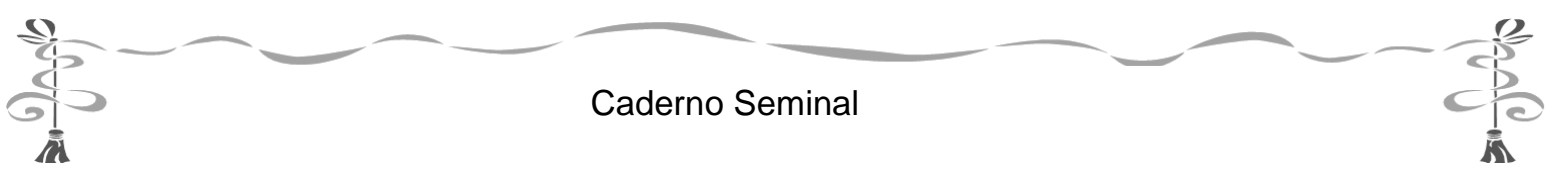

O que nos chamou muito a nossa atenção é que na interação seguinte, o interagente estadunidense retomou a questão dos estereótipos, e veja como a interagente brasileira lidou com aquela situação, conforme é asseverado no diário da interagente.

(...) ele voltou ao assunto dos estereótipos, dizendo que ele estava pensando no fato de eu ter dito que ele era sério. Ele me disse ter chegado à conclusão de que ele deve estar mesmo muito sério, pois está muito preocupado com o que vai fazer depois da faculdade. Eu disse somente que tinha entendido o que ele havia dito e procurei não continuar o assunto, para não virar uma conversa "de divã" ou entre amigos, por exemplo, um dando conselhos para o outro. Perguntei então o que ele achava dos brasileiros, qual era o estereótipo do brasileiro pra ele. Ele se referiu a alguns aspectos de estética e disse que nos fazíamos festa a todo momento, colocação esta que achei um pouco estranha e não concordei. Ele continuou a elencar alguns aspectos da cultura e depois pediu que eu contasse a ele algo que ele havia esquecido de mencionar. Tal assunto não estava me agradando, então disse que também não lembrava mais de nada, para que pudéssemos mudar o foco da nossa conversa. (Excerto 17: Diário da Interagente Brasileira)

Acreditamos que este assunto não estava interessando tanto a interagente brasileira em detrimento da experiência negativa que vivenciara no qual perdera o seu interagente estadunidense. Mas o que podemos depreender dos excertos supracitados são os possíveis reflexos do trabalho de preparação realizado antes do início das interações e mediação em teletandem. Conforme asseverado por VIEIRAABRAHÃO (2009, p. 13) foram lidos textos teóricos e discutidas questões importantes questões relacionadas ao processo de aprender e de ensinar línguas no contexto virtual, dentre elas, a questão de abordagens de diferenças culturais. A nosso ver e corroborado por outros excertos, a professora propulsiona $\mathrm{O}$ desenvolvimento de uma competência intercultural, estimulando que a interagente respeite a cultura do outro e a compreenda os possíveis conflitos culturais que possam surgir.

\section{Outras competências}

$\mathrm{Na}$ análise dos registros é possível depreender outras competências que emergiram dentro do contexto teletandem e que serão apresentadas e discutidas em um outro artigo acadêmico-científico e na tese que se encontra em desenvolvimento, a saber: a) competência multimodal que envolve, dentre outros fatores, o professor saber quais seriam os gêneros (primários e/ou secundários) ${ }^{72}$ que poderiam ser utilizados em

\footnotetext{
72 Bakhtin (1979/2003, p. 263) assevera que os gêneros discursivos primários (simples) integram os secundários (complexos), o que, por sua vez, significa que o desenvolvimento se dá por continuidade e ruptura entre os mesmos, em um "processo de desenvolvimento e reestruturação do sistema de produção da linguagem" (cf. Schneuwly, 2004, p. 29). Para uma discussão mais aprofundada sobre gêneros do discurso do círculo de Bakhtin, veja Silva (2008), Silva \& Rocha (2006), Rocha, (2006) e Rojo (2005).
}

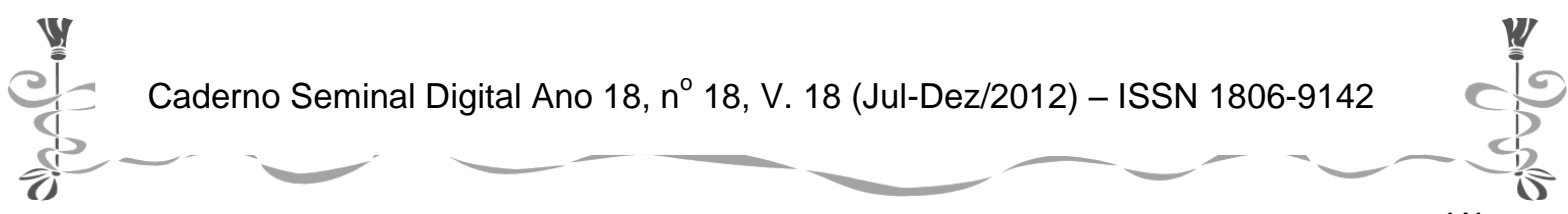




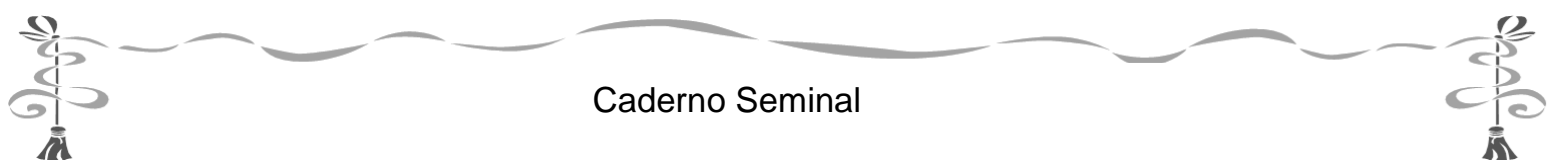

sua sala de aula e saber adequá-los eficazmente neste âmbito pedagógico às múltiplas linguagens hoje em voga na contemporaneidade.

Em outras palavras, envolve um conjunto de múltiplas formas de representação ou códigos semióticos que, através de meios próprios e independentes, realizam sistemas de significados; b) competência linguístico-comunicativa na própria língua materna ou metalinguagem, que envolve ter o conhecimento do funcionamento e do uso da sua própria língua materna e dos princípios culturais que a alicerçam. Não basta, a nosso ver, saber explicar as regras que subjazem a estrutura e o uso da nossa língua, mas as variáveis culturais que, de uma forma direta ou indireta, se encontram implícitas.

\title{
Considerações Finais
}

\author{
“Temos de examinar não somente o papel da tecnologia na \\ aprendizagem de línguas, mas também o papel da \\ aprendizagem de línguas em uma sociedade de tecnologia de \\ informação". (Braga, 2004, p. 24 - Ênfase adicionada)
}

Neste artigo apresentamos e refletimos criticamente acerca das competências que são (re) construídas pelos participantes da pesquisa dentro do teletandem, a saber: implícita, teórica, aplicada e intercultural. Pretendemos, com isso, suscitar o interesse de teóricos e profissionais da linguagem para a vertente da (trans) formação de professores de línguas para o meio virtual sob diferentes olhares, visando que a mesma continue a se desenvolver no sentido de buscar, com crescente intensidade e propiciar maneiras efetivas de formar o profissional de LE integralmente.

Isto, por sua vez, implicará inserir os alunos em (trans) formação inicial em práticas de linguagem historicamente constituídas, oferecendo oportunidades para que eles possam delas se apropriar. Entendemos que o processo educacional pautado nesta perspectiva é pertinente dentro do contexto em foco porque: a) gera interações significativas; b) propicia ação colaborativa e; c) considera as competências já desenvolvidas para o desenvolvimento de outras.

Para tal intento, é necessário uma mudança até certo paradigmáticas nos nossos cursos de formação inicial de professores de línguas presenciais (que são mais de 1.100 centros de formação de professores no Brasil) e especialmente os virtuais (visto que é um contexto inovador de formação de professor de línguas), incorporarem os paradigmas advindos da prática crítico-reflexiva, tendo como esteio a teoria bakhtiniana de gêneros, alinhavada aos pressupostos do letramento digital.

Ecoando Paiva (2007, p. 318), esperamos que no futuro próximo, "quando alguém escutar a banda "Mastruz com Leite" cantar:

The book is on the table, table, table

The dog is on the table, table, table

The cat is on the table, table, table

The chicken is on the table, table, table

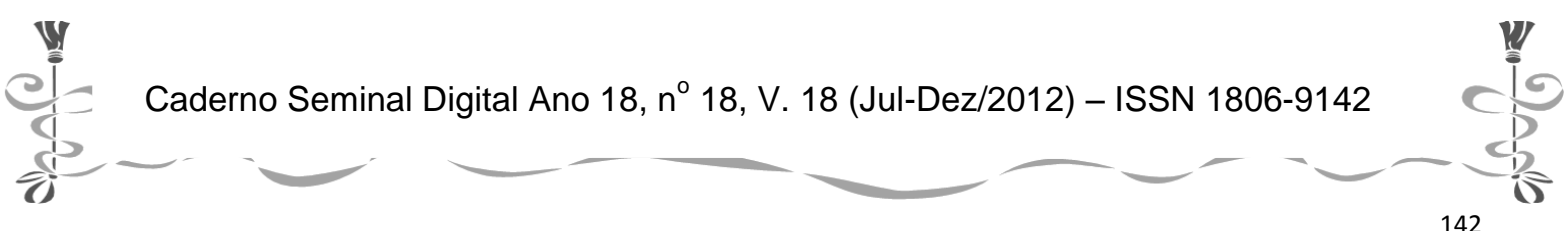




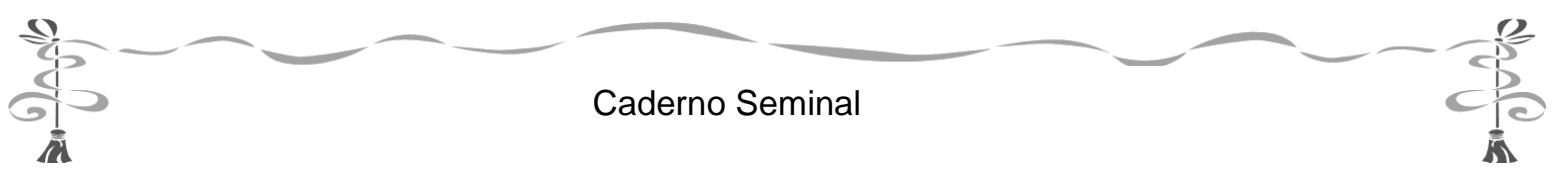

And everybody is on the table, table, table

Table, table, table, table!!!

And everybody is on the table, table, table!!

" (...) não se recorde (...) de suas experiências como aprendiz de inglês",

e acrescentamos, nem de suas experiências advindas dos cursos de formação (inicial e/ou contínua) de professores, sejam eles presenciais e/ou virtuais. Esperamos que os cursos de (trans) formação inicial e/ou contínua possam refletir em maneiras práticas e eficazes de incorporarem as variáveis elicitadas neste artigo em suas respectivas salas de aula de LEs. É necessário que delimitemos, mas também atravessemos as fronteiras digitais em e/ou fora dos âmbitos educacionais.

\section{Referências}

ALMEIDA FILHO, J.C. P. Dimensões comunicativas no ensino de línguas. Campinas: Pontes, 1993.

ALMEIDA FILHO, J.C.P. (Org.) O Professor de Lingua Estrangeira em Formação Campinas: Pontes, 1999.

ALMEIDA FILHO, J. C. P. O Professor de Língua (s): Profissional, Reflexivo e Comunicacional. Revista Horizontes de Linguistica Aplicada, vol. 3, n.1, 2004.

ALMEIDA FILHO, J. C. P. (Re) Conhecer e desenvolver a competência profissional de professores de língua estrangeira. Contexturas: Ensino Crítico de Língua Inglesa, vol. 9, p. 9-20, 2006.

ALVARENGA, M. B. Configuração de competências de um professor de língua estrangeira (Inglês): Implicações para a formação em serviço. Dissertação de Mestrado em Linguística Aplicada Instituto de Estudos da Linguagem, Unicamp, Campinas, 1999.

ARAÚJO, J. C. (Org.) Internet \&o Ensino - Novos gêneros, outros desafios. $1^{\text {a }}$ ed. Rio de Janeiro: Lucerna, 2007, v. 1, 2007.

BAKHTIN, M. V. Speech Genres \& Other Late Essays. Austin: University of Texas Press, 1986.

BAKHTIN, M. V. (1953/1979). Estética da Criação Verbal. Martins Fontes, São Paulo, 2003.

BAKHTIN, M. V. (1929). Marxismo e Filosofia da Linguagem. São Paulo: Hucitec, 2004.

BARBOSA, J. P. Trabalho com Gêneros de Discurso: Uma Perspectiva para o Ensino de Lingua Portuguesa. Dissertação (Mestrado em Linguística Aplicada e Estudos da Linguagem) LAEL/PUC-SP, 2001.

BARCELOS, A. M. F. Crenças sobre ensino e aprendizagem de línguas: Reflexões de uma década de pesquisa no Brasil. In: ALVAREZ, M. L. O.; SILVA, K. A.; (Orgs.) Linguística Aplicada: Múltiplos Olhares - Estudos em homenagem ao Professor Dr. José Carlos Paes de Almeida Filho, Campinas, SP: Pontes, p. 27-70, 2007.

BARCELOS, A. M. F.; VIEIRA-ABRAHÃO, M. H. (Orgs.) Crenças e Ensino de Linguas: Foco no professor, no aluno e na formação de professores. Campinas, SP: Pontes Editores, 2006.

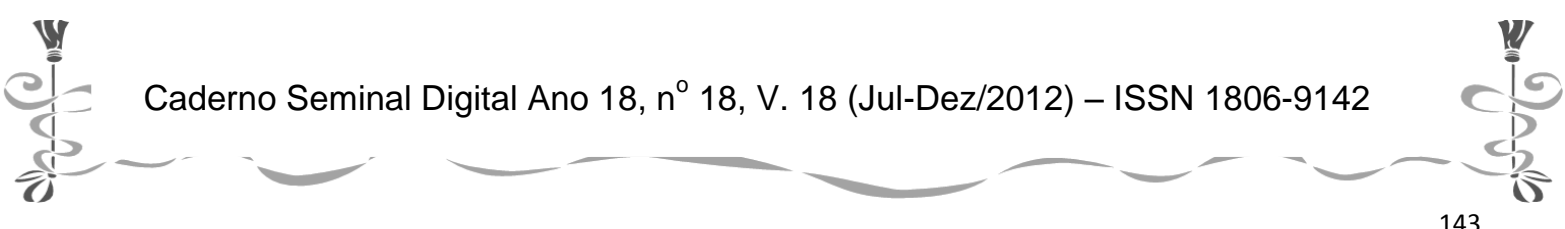




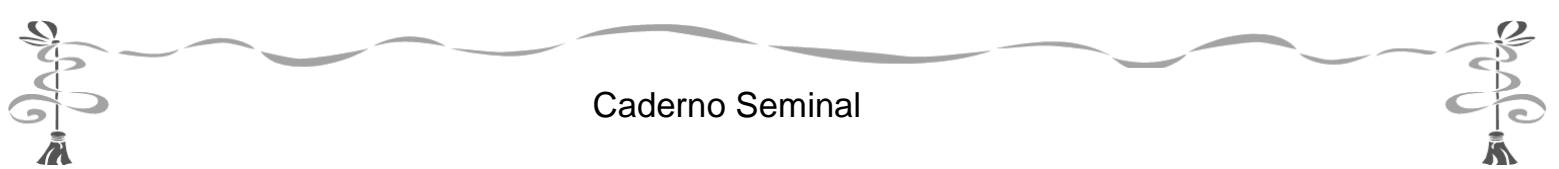

BASSO, E. As competências na contemporaneidade e a formação do professor de LE. In: SILVA, K. A.; ALVAREZ, M. L.(Orgs.) Perspectivas de Investigação em Linguística Aplicada. Campinas-São Paulo, SP: Pontes Editores, p. 127-156, 2008.

BASSO, E. A. A construção social das competências necessárias ao professor de língua estrangeira: entre o real e o ideal um curso de Letras em Estudo. Tese de Doutorado em linguística Aplicada - Instituto de Estudos da Linguagem, Unicamp, Campinas, 2001.

BEDRAN, P. F. (Re)construção das crenças do par interagente e dos professores-mediadores no teletandem. Dissertação (Mestrado em Estudos Linguísticos) - Instituto de Biociências, Letras e Ciências Exatas, Universidade Estadual Paulista, São José do Rio Preto, 2008.

BRAGA, D. B. A comunicação interativa em ambiente hipermídia: as vantagens da hipermodalidade para o aprendizado no meio digital. In: MARCUSCHI, L. A.; XAVIER, A. C. (Orgs.). Hipertexto e Gêneros e Digitais: novas formas de construção do sentido. Rio de Janeiro: Editora Lucerna, v. 1, p. 144-162, 2004.

BRONCKART, J. P. Atividade de linguagem, textos e discursos: Por um interacionismo sóciodiscursivo. Tradução de Anna Rachel Machado, Péricles Cunha. São Paulo: EDUC, 1999.

BUZATO, M. E. K. Entre a fronteira e a periferia: linguagem e letramento na inclusão digital. Tese (Doutorado em Linguística Aplicada), Campinas, SP: UNICAMP, 2007.

CELANI, M. A. A. Transdisciplinaridade na linguística aplicada no Brasil: In: SIGNORINI, I.; CAVALCANTI, M. C. (Orgs.) Linguistica Aplicada e Transdisciplinaridade. Campinas, Mercado de Letras, p. 129-142, 1998.

COELHO, H. S. H. "É possível aprender inglês em escolas públicas?" Crenças de professores e alunos sobre o ensino de inglês em escolas públicas. Dissertação (Mestrado Estudos Linguísticos) - Faculdade de Letras, UFMG, Belo Horizonte, 2005.

CRISTOVÃO, V. L. L. A Implicação da Constituição de Objetivos para o Ensino de Línguas Estrangeiras. In: GIMENEZ, M. P (Org.). Contribuições na Área de línguas estrangeiras. Londrina: Moriá, p. 105-119, 2005.

FARACO, C. A. Linguagem \& Diálogo: as ideias linguísticas do círculo de Bakhtin. Curitiba, PR: Criar Edições, 2006.

FIGUEIREDO, F. J. Q. (Org.) A aprendizagem colaborativa de línguas. Goiânia: Editora da UFG, 2006.

FREIRE, M. M. Interfaces digitais na formação inicial do professor de inglês: possibilidades e implicações. Cadernos de Resumos do II Congresso Internacional da ABRAPUI, Junho, 2009.

GURIBE, F; WASSON, B. The ethnography of distributed collaborative learning. Disponível em: $<$ http://newmedia.colorado.edu/cscl/148.html $>$.

HINE, C. Virtual ethnography. Conference Proceeding of Internet Research and Information for Social Scientists, pp. 25-27 March, 1998, Bristol, U.K. Disponível em: <http://www.sosig.ac.uk/iriss/papers/paper16.htm $>$.

KALAJA, P.; PAIVA, V. L. M. O.; BARCELOS, A. M. F. (Orgs.) . Narratives of learning and teaching EFL. 1a. ed. Londres: Palgrave/Macmillan, 2008.

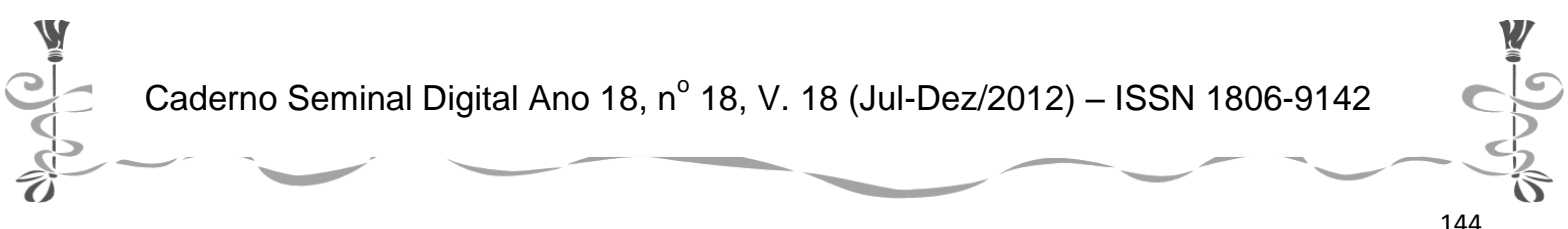




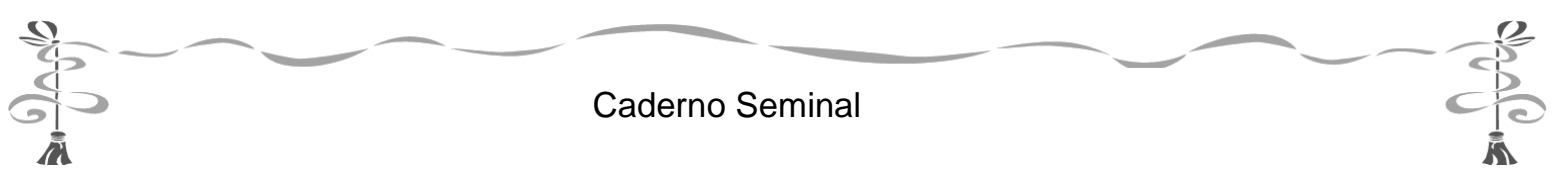

KFOURI-KANEOYA, M. L. C. A formação inicial de professores de línguas para o Teletandem: um diálogo entre crenças, discurso e reflexão. Tese (Doutorado em Estudos Linguísticos) Instituto de Biociências, Letras e Ciências Exatas, Universidade Estadual Paulista, São José do Rio Preto, 2008.

KRESS, G. Gains and losses: New forms of texts, knowledge and learning. Computers and Composition, vol. 22, p. 5-22, 2005.

KORTHAGEN, F.A; KESSELS, J.P.A.M Linking theory and practice: Changing the pedagogy of teacher education. Educational Researcher, 28(4): 4-17, 1999.

MENDES, C. M. Crenças sobre a língua inglesa: O antiamericanismo e sua relação com o processo de ensino-aprendizagem de professores em formação. Dissertação (Mestrado em Estudos Linguísticos) - Instituto de Biociências, Letras e Ciências Exatas, Universidade Estadual Paulista, São José do Rio Preto, 2009.

MENDES, E. A perspectiva intercultural no ensino de línguas: uma relação "entre culturas". In: ALVAREZ, M. L. O.; SILVA, K. A. (Orgs.) Linguistica Aplicada: Múltiplos Olhares, Campinas, SP: Pontes, p. 119-140, 2007.

MESQUITA, A. A. F. Crenças e práticas de avaliação no processo interativo e na mediação de um par no tandem a distância: um estudo de caso. Dissertação (Mestrado em Estudos Linguísticos) Instituto de Biociências, Letras e Ciências Exatas, Universidade Estadual Paulista, São José do Rio Preto, 2008.

MOITA LOPES, L. P. Uma linguística aplicada mestiça e ideológica: interrogando o campo como linguista aplicado. In: MOITA LOPES, L. P. (Org.) Por uma linguística aplicada indisciplinar. São Paulo, SP: Parábola Editorial, p. 13-44, 2006.

MOITA LOPES, L. P. (Org.) Por uma linguística aplicada indisciplinar. São Paulo, SP: Parábola Editorial, 2006.

MOITA LOPES, L. P. Oficina de Linguística Aplicada. Campinas: Mercado de Letras, 1996.

PAIVA, V. M. O. A complexidade da aquisição de segunda língua: revisando e conciliando teorias (em processo de produção) 2008.

PAIVA, V. L. M. Linguagem, gênero e aprendizagem de língua inglesa. In: ALVAREZ, M. L. O.; SILVA, K. A. (Orgs.) Lingüistica Aplicada: Múltiplos Olhares - Estudos em homenagem ao Professor Dr. José Carlos Paes de Almeida Filho, Campinas, SP: Pontes, p. 305-320, 2007.

PAIVA, V. L. M. O. A identidade do professor de inglês. APLIEMGE: ensino e pesquisa. Uberlândia: APLIEMGE/FAPEMIG, n.1, 1997. p. 9-17

PENNYCOOK, A. Uma linguística aplicada transgressiva. In: In: MOITA LOPES, L. P. (Org.) Por uma linguística aplicada indisciplinar. São Paulo, SP: Parábola Editorial, p. 67-83, 2006.

PERRENOUD P. Construir as Competências desde a Escola. Porto Alegre: Artmed, 1999.

PERRENOUD P. Novas Competências para Ensinar. Porto Alegre: ARTMED. 2000.

PERRENOUD P. Formando o profissional competente. Porto Alegre: ARTMED. 2001.

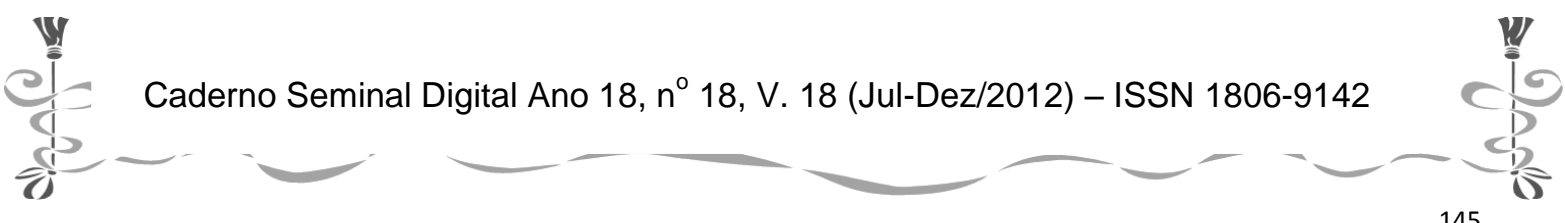




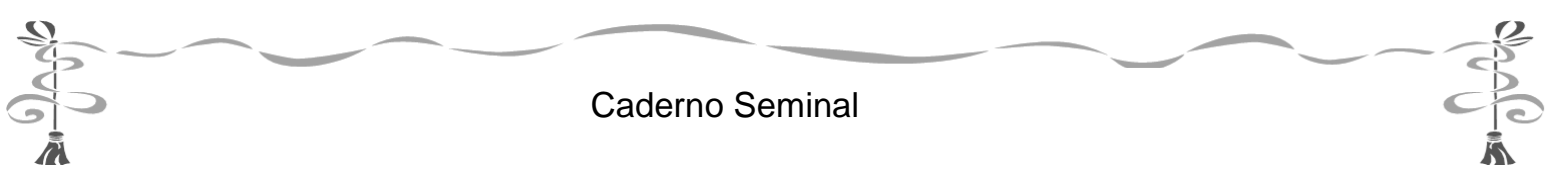

ROCHA, C. H. O ensino de LE (Inglês) para crianças por meio de gêneros: um caminho a seguir. Contexturas: Ensino Crítico de Lingua Inglesa, vol. 10, p. 65-94, 2006.

ROJO, R. H. R. "Fazer linguística aplicada em perspectivas sócio-histórica: Privação sofrida e leveza de pensamento". In: MOITA LOPES, L. P.. (Org.). Por uma Linguística Aplicada Indisciplinar. $1^{a}$ ed. São Paulo: Parábola, p. 253-276, 2006.

ROJO, R. H. R. Letramentos múltiplos, escola e inclusão social. 1'. ed. São Paulo: Parábola Editorial, 2009.

ROJO, R. "Gêneros do discurso e gêneros textuais: questões teóricas e aplicadas". In: BONINI, A.; MEURER, J. L.; MOTTA-ROTH, D. (Orgs.) Gêneros: teorias, métodos, debates. São Paulo, p.184-207, 2005.

ROJO, R. H.; BARBOSA, J. P.; COLLINS, H. "Letramento digital: um trabalho a partir dos gêneros do discurso". In: KARWOSKI, A. M.; GAYDECZKA, B.; BRITO, K. S. (Orgs.) Gêneros Textuais: Reflexões e Ensino. $2^{a}$ Ed. rev. e ampliada, Rio de Janeiro: Lucerna, p. 107-130, 2006.

SADALLA, A. M. F. A, BACCHIEGGA, F., PINA, T. A.; WISNIVESKY, M. "Psicologia, Licenciatura e Saberes Docentes: Identidade, Trajetória e Contribuições". In: AZZI, R.G. \& SADALLA, A.M.F.A. (Orgs.) Psicologia e Formação Docente: Desafios e Conversas. São Paulo: Casa do Psicólogo, 2002, p. 47-92.

SALOMÃO, A. C. B. O professor mediador: processos de gerenciamento e estratégias pedagógicas utilizadas na mediação dos pares no teletandem e seus reflexos nas práticas pedagógicas dos interagentes. Dissertação (Mestrado em Estudos Linguísticos) - Instituto de Biociências, Letras e Ciências Exatas, Universidade Estadual Paulista, São José do Rio Preto, 2008.

SANDEI, M. L. R. "Papel do Sentido de Plausibilidade na Formação em serviço dos Professores de Língua Estrangeira”. In: ALVAREZ, M. L.; SILVA, K. A. (Orgs.) Linguística Aplicada: Múltiplos Olhares, Campinas: Pontes, 2007.

SILVA, K. A. Crenças e aglomerados de crenças de alunos ingressantes em Letras (Inglês). Dissertação (Mestrado em Linguística Aplicada) - Instituto de Estudos da Linguagem, Unicamp, Campinas, 2005.

SILVA, K. A.; ROCHA, C. H. “A formação do professor de LE (Inglês): Investigando a possível relação entre as teorias dos gêneros e as competências desejáveis". Contexturas: Ensino Crítico de Inglês, APLIESP, vol. 10, p. 45-64, 2006.

SOUZA, R. A. Aprendizagem de línguas em tandem: estudo da telecolaboração através da comunicação mediada pelo computador. Tese de Doutorado em Estudos Linguísticos Faculdade de Letras, UFMG, 2003.

TELLES, J. A. (Org.). Teletandem: Um contexto virtual, autônomo e colaborativo para aprendizagem de línguas estrangeiras no Século XXI. 1 ed. Campinas: Pontes Editores, 2009.

TELLES, J.A.; VASSALLO, M.L. "Foreign language learning in-tandem: Teletandem as an alternative proposal in CALLT". The ESPecialist, 27 (2), 189-212, 2006.

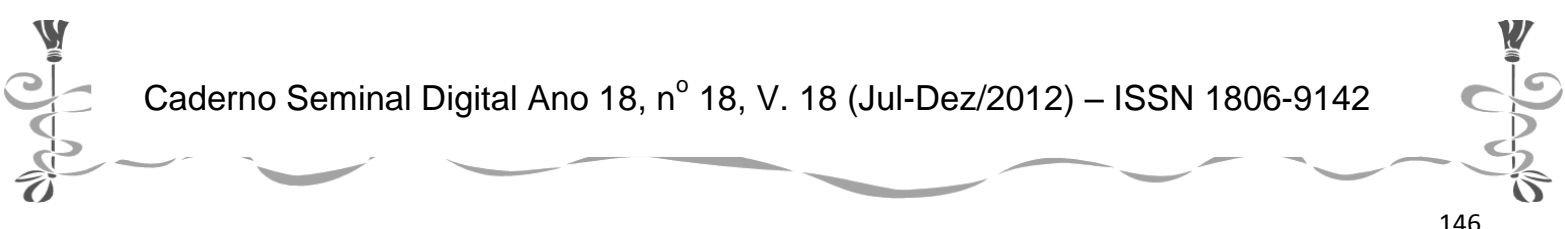




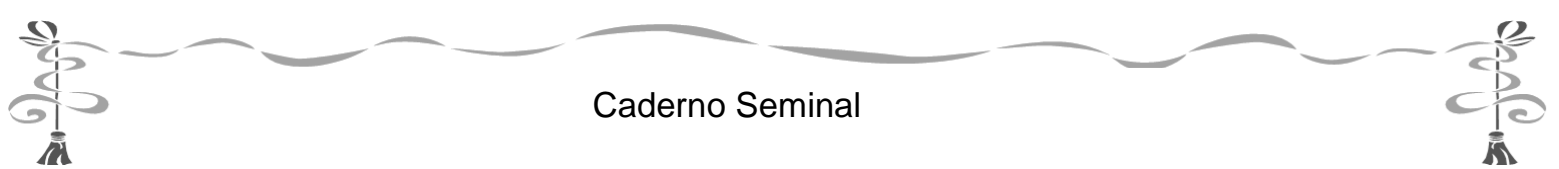

SCHNEUWLY, B. "Gêneros e tipos de discurso: considerações psicológicas e ontogenéticas". In: SCHNEUWLY, B. et al. (Orgs.). Gêneros Orais e Escritos na Escola, p. 2139, 2004.

SERRANI, S. Discurso e Cultura na Aula de Língua: Currículo- Leitura - Escrita. Campinas: Pontes, 2005.

SILVA, K. A. "As competências do professor contemporâneo de língua estrangeira (Inglês) para o meio virtual". In: ROCHA, C. H.; BASSO, E. (Orgs.) Ensinar e aprender língua estrangeira nas diferentes idades: Reflexões para professores e formadores. São Carlos, São Paulo: Clara Luz, p. 217-236, 2008.

SILVA, K. A.; ROCHA, C. H. “A formação do professor de LE (Inglês): Investigando a possível relação entre as teorias de gêneros e as competências desejáveis". In Contexturas: Ensino Crítico de Lingua Inglesa, no prelo, 2006.

SILVA, K. A.; ROCHA, C. H.; SANDEI, M. L. R. "A importância do estudo das crenças na formação de professores de línguas". In . Contexturas: Ensino Crítico de Inglês, APLIESP, vol. 8, p. 19-40, 2005.

VASSALLO, M.L.; TELLES, J.A. "Foreign language learning in-tandem: Theoretical principles and research perspectives". The ESPecialist, 27(1), 83-118, 2006.

VIEIRA-ABRAHÃO, M. H. Relatório Científico relativo ao período 30/04/2008 a 29/04/2009. Grupo de Pesquisa "Teletandem Brasil: Línguas Estrangeiras para todos", 2009 .

VIEIRA-ABRAHÃO, M. H. A formação inicial e o desenvolvimento profissional do professor de línguas estrangeiras: práticas e pesquisas. Horizontes, Brasília, v. 5, n. 2, p. 8 23, 2006.

VIEIRA-ABRAHÃO, M. H. (Org.) Prática de ensino de língua estrangeira: Experiências e reflexões. Campinas: Pontes Editores, ArteLíngua, 2004.

VIEIRA-ABRAHÃO, M. H. “A formação inicial e o desenvolvimento profissional do professor de línguas estrangeiras: práticas e pesquisas". Horizontes de Linguística Aplicada. Instituto de Letras, Programa de Pós-Graduação em Linguística Aplicada, Brasília (DF), vol. 5, n. 2, p. 07-23, 2006.

VIEIRA-ABRAHÃO, M. H. V. Conflitos e incertezas na renovação da prática de sala de aula do professor de lingua estrangeira: um estudo etnográfico. Tese (Doutorado em Linguística Aplicada) Instituto de Estudos da Linguagem, Unicamp, Campinas, 1996.

VYGOTSKY, L. Mind in Society. Cambridge, M.A.: Harvard University Press, 1978.

VYGOTSKY, L. S. A Formação Social da Mente. São Paulo: Martins Fontes, 1998.

VYGOTSKY, L. S. A Construção do Pensamento e da Linguagem, São Paulo: Martins Fontes, 2001.

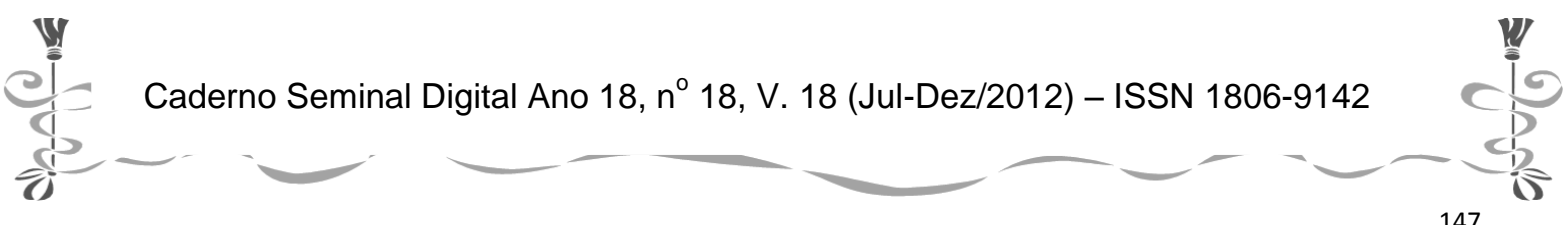

